\title{
BEHAVIOR AND INFLUENCE MECHANISMS OF ENTERPRISES USING GOVERNMENT SUBSIDIES: EVIDENCE FROM CHINA
}

\author{
Xiaochang YAN ${ }^{(D)}$, Guitian HUANG ${ }^{\mathbb{D}} 2^{*}$ \\ ${ }^{1}$ National School of Development, Peking University, Beijing, China \\ ${ }^{2}$ School of Economics, Peking University, Beijing, China \\ Received 28 December 2020; accepted 25 April 2021; \\ first published online 24 August 2021
}

\begin{abstract}
This study investigates the effects of different subsidy use patterns on economic performance, the effect mechanisms, and differences among enterprises with heterogeneous economic performance. A theoretical model is built to analyze the factors influencing subsidy use. Applying ordinary least squares and panel quantile regressions on panel data of China's 3,565 A-share listed companies from 2007 to 2017, we find that subsidies can significantly improve economic performance. Specifically, enterprises usually use subsidies in three different ways (i.e. R\&D input, expansion of production capacity for existing products, and human resource training), and the positive impact of these three use patterns on economic performance is moderated by two factors (i.e. the proportions of both $\mathrm{R} \& \mathrm{D}$ operating expenses and human resource training cost) in different degrees. Moreover, the effects are more significant in the lower quantile of economic performance; hence, heterogeneity of economic performance must be considered when formulating relevant policies.
\end{abstract}

Keywords: economic performance, government subsidy, moderating effect, panel quantile regression, R\&D, China.

JEL Classification: D24, G30, G38.

\section{Introduction}

Scientific and technological (sci-tech) innovations provide strategic support for enhancing social productivity. Hence, China has actively adopted the strategy of innovation-driven development. Since the $18^{\text {th }}$ National Congress of the Communist Party of China, this strategy has produced a succession of achievements that moved the country into $14^{\text {nd }}$ place in the Global Innovation Index in 2019 from 34 $4^{\text {th }}$ in 2012. Through innovation, many Chinese enterprises have attained self-transcendence, matching and even surpassing global leaders in certain fields while realizing the strategy of "Wisdom in China." Enterprises have become the core force turning China into an innovation-oriented country. Since the "National Pro-

*Corresponding author. E-mail: huanggtpku@163.com

Copyright (c) 2021 The Author(s). Published by Vilnius Gediminas Technical University

This is an Open Access article distributed under the terms of the Creative Commons Attribution License (http://creativecommons. org/licenses/by/4.0/), which permits unrestricted use, distribution, and reproduction in any medium, provided the original author and source are credited. 
gram for Long- and Medium-term Scientific and Technological Development (2006 to 2020)" was enacted in 2006, a series of policies related to R\&D activities have been issued, including those on sci-tech inputs, human resources, sci-tech innovation bases, and government procurement. The "Opinions on Strengthening the Dominant Position of Enterprise Technological Innovation to Comprehensively Improve Innovation Capabilities of Enterprises" promulgated by the General Office of the State Council in 2013 further clarified the dominant role of enterprises in sci-tech innovation and improved relevant policies to stimulate $\mathrm{R} \& \mathrm{D}$ innovation activities.

Sci-tech innovation policies aim to increase enterprises' R\&D inputs and stimulate innovation that can drive the comprehensive, healthy, and sustainable development of China's economy and society. However, several issues must be studied systematically, including how enterprises apply sci-tech innovation policies to R\&D activities and how subsidies affect their economic performance.

Sci-tech innovation policy has been a hot research topic in recent years, and it is usually carried out from four aspects, including financial support for R\&D activities, development through innovation, support for sectorial programs, and university-industry-government collaboration (Jugend et al., 2020). Among these, government subsidies have received much attention as they are easily measured. However, extant studies have reached inconsistent conclusions. Some have argued that government subsidies can significantly improve economic performance. Cin et al. (2017) demonstrated that subsidies significantly and positively affected economic performance in South Korea. Guo et al. (2016) not only demonstrated this result in China but also found that subsidy policies issued by local governments are more effective than those issued by the central government. Focusing on the French cluster policy, Hassine and Mathieu (2020) demonstrated that enterprises inside clusters generally receive more subsidies and invest more in R\&D activities, which shows a significant leverage effect of subsidies with lagging performance. Jose and Sharma (2020) found the heterogeneity of additionality effect of government support for R\&D and innovation exists among enterprises in different industries and of different sizes, by structuring a meta-regression analysis. However, a southern Italian study showed that subsidies had a negative effect in the short and long terms (Bernini \& Pellegrini, 2011). Russo et al. (2011) found that subsidies did not significantly improve the economic output of agricultural enterprises and were used inefficiently. McKenzie and Walls (2013) reported similar conclusions with a sample of Australian film companies. Kim (2021) found that although subsidies can facilitate innovation, they do not contribute to the process of transforming innovation into economic growth. Chen and Breedlove (2020) found that government subsidies have a negative impact on both comprehensive innovation efficiency and pure technical efficiency of the Chinese high-tech sport firms, and the impact shows heterogeneity among enterprises of different sizes and with different R\&D staff sizes. The divergence of the above opinions results from various factors, including enterprise heterogeneity, subsidy use patterns, and differing socioeconomic environments across countries.

Some studies have examined the mechanisms through which government subsidies affect economic performance and found some influencing mechanism factors, such as time lag of investments, subcontracting, government corruption, uncertainties, technology conversion 
efficiency, subsidizing way, etc. Lin et al. (2018) constructed a strategic exercise of an options model linking business decisions and government subsidies, and demonstrated that subsidies improved economic performance through a reduction in the time lag of investments and the positive benefit-cost ratio of subsidies. Kim (2021) demonstrated that the impact of subsidies on enterprises' innovation performance is moderated by subcontracting, and that this effect is significantly stronger in enterprises that rely heavily on subcontracting. Lai (2020) found that the ultimate impact of enterprises' rent-seeking on their R\&D behavior and productivity is affected by the level of government corruption. Chen et al. (2020) developed a theoretical framework and illustrated that the efficiency of agricultural subsidy is significantly influenced by uncertainties (output, costs, and price) and technology conversion efficiency. The subsidizing way was found to affect the innovative behavior and economic profits of enterprises in a duopoly study, and bilateral subsidy is more effective than unilateral subsidy (Nie et al., 2020).

Although research on the influence mechanisms of subsidies remains relatively insufficient, scholars have made abundant achievement on subsidies' impact of R\&D input. Some studies argued that subsidies have a significant leveraging effect (Becker, 2015; Carboni, 2017; Gomez \& Sequeira, 2014) while others showed a crowding-out effect (Boeing, 2016; Garcia \& Mohnen, 2010) on enterprise R\&D inputs. Yu et al. (2016) found that subsidies and R\&D inputs have an inverted-U shape relationship, while Dai and Cheng (2015) illustrated an S-shaped relationship using a sample of Chinese manufacturing enterprises. Shen and Lin (2020) found that even though subsidies have not significantly increased the R\&D inputs, they generated a significant positive impact on R\&D intensity of high-tech industries. Szucs (2020) demonstrated that although the average effect of subsidies on the improvement of private $R \& D$ is not significant, the effect shows heterogeneity among different enterprises, especially the promotion effect on private $R \& D$ input in smaller enterprises and more $\mathrm{R} \& \mathrm{D}$-intensive enterprises is more obvious. In addition, based on a sample of Vietnamese enterprises, Tebourbi et al. (2020) found that managerial overconfidence and government ownership are factors that have a positive impact on R\&D input and play a moderating role. Obviously, there is no consistent conclusion about the impact of subsidies on R\&D input. Moreover, extant research still lacks the consideration of enterprises' use of subsidies for purposes other than R\&D activities, as well as the influencing factors and mechanisms of enterprises' decisions on different subsidy use patterns.

Considering the above-mentioned shortcomings of extant researches, this study not only constructs a theoretical model to deduce the influencing factors, but also investigates the effects of three government subsidies use patterns on enterprise economic performance and the mechanism of such effects using panel data of China's A-share listed companies. Specifically, this study focuses on the following questions: 1) What are the actual effects of enterprises' different subsidy use patterns on economic performance? 2) What are the mechanisms of such effects? 3) Whether such effects and mechanisms present differences among enterprises with heterogeneous economic performance?

The marginal contributions of this study are as follows. First, to make up for the relative lack of research on the influence mechanism of subsidies, this paper is the first study to investigate the actual effects of government subsidies on enterprises' economic performance 
and the mechanisms of such effects from the perspective of three use patterns-R\&D input, expansion of production capacity for existing products, and human resource training-that not only provides a realistic test of the efficiency of subsidies but also a detailed examination of their influence mechanisms. Second, although some existing researches have studied the impact of government subsidy on economic performance and $\mathrm{R} \& \mathrm{D}$ input, there is no consistent conclusion. This paper is a further examination of these hotly debated questions with the data of Chinese listed companies by using different research methods. Third, in terms of research methods, most extant studies use empirical research. Even if there are a few theoretical research articles, they only describe and deduce the theoretical model in detail, but lack the empirical test using real economic data. Our study fully combines the theoretical and empirical research methods. By constructing a theoretical analysis model, this study identifies the key factors that affect subsidy use, thereby determining the moderating variables through which economic performance is affected. With the identified factors, an empirical model is further constructed to provide empirical evidence for policy improvement to increase the subsidy use efficiency. Fourth, through panel quantile regression, this study further identifies the heterogeneity of both the actual effects of subsidies on enterprise sci-tech innovation and the mechanism of such effects.

\section{Literature review and hypotheses development}

\subsection{Government subsidies and enterprise economic performance}

Market failure refers to firms' inability to achieve optimal resource allocation, resulting in inefficient economic operations. In a dysfunctional market, R\&D impetus is remarkably reduced to the detriment of $\mathrm{R} \& \mathrm{D}$ innovation and realization of economic benefits (Arrow, 1962). To rectify market failure, governments may take actions to regulate market resource allocation; government subsidies are widely used worldwide as effective policy instruments. First, subsidies can directly offset the underfunding of R\&D activities and promote economic performance thereby increasing the R\&D input scale and improving enterprises' technological innovation levels (Colombo et al., 2011). Second, through a market signaling mechanism, subsidies can stimulate and guide private investment, providing more market financing channels and reducing the negative impact of financing constraints on economic performance (Kleer, 2010). Third, subsidies can help enterprises reduce production costs required to apply emerging technologies that go beyond their innovation abilities and increase production scales and profits (Sissoko, 2011). Fourth, by enhancing the short-term solvency of enterprises, subsidies can improve enterprises' economic performance (Tzelepis \& Skuras, 2004).

However, some studies have shown that the subsidy use efficiency is relatively low and therefore, does not significantly improve enterprises' economic output or competitiveness (McKenzie \& Walls, 2013). Some scholars have even found that subsidies may negatively affect economic performance (Bauer et al., 2012). As the granting of subsidies is based on past events rather than on promising prospects, rent-seeking behaviors often exist in enterprises such that government subsidies have no significant positive impact on performance (Jin et al., 2018), or even be harmful to economic performance (Baumol, 1990; Brou \& Ruta, 2013; Murphy et al., 1991). This scenario usually happens when the reward to rent-seeking is 
more than that to the productive activities (Lai, 2020). Some enterprises may use fraudulent means to meet the criteria for subsidies, thereby misallocating resources and greatly reducing both subsidy distribution efficiency and incentive effect (Li et al., 2020). Second, the government-enterprise relationship significantly affects the subsidy amounts obtained by enterprises; those with closer government ties can often obtain greater subsidies (Tao et al., 2017). Third, subsidies come from taxes, which in turn come from enterprises. An increase in subsidies results in higher taxes, lowering enterprise income. Fourth, even if enterprises use subsidies for $R \& D$ activities, the efficiency of subsidy using is usually low due to the commonly used policy of uniform research subsidy, which can even accentuate the dynamic misallocation in the economy (Akcigit et al., 2021).

To sum up, government subsidies have both spillover and crowding-out effects on enterprises' R\&D activities, which results in uncertain impacts on economic performance (Zhao et al., 2018). In fact, more and more research found that the impact of government subsidies on enterprises' R\&D investment is not simply a spillover effect or crowding-out effect (Guellec \& van Pottelsberghe de la Potterie, 2000; Clausen, 2009; Xiao et al., 2013). These two effects exist at the same time, but show different net effects in different studies, for the reason that a variety of factors exert varying degrees of influence under different circumstances, including the forms and time of subsidy, various social and cultural factors in different countries and regions, etc.

As the largest developing country, China is still in a crucial period of economic transformation and upgrading, and has not yet established a complete market mechanism and its intellectual property protection system is still incomplete. Intellectual property protection is generally considered as an effective way to reduce the risk of imitating innovative technology and knowledge and to increase the benefits of innovation, which is conducive to enterprises' innovation (Kanwar \& Evenson, 2003). Good intellectual property protection can improve the exclusiveness of innovative technology, that is, it can enhance the ability of enterprises to internalize the benefits of innovation, and then increase enterprises' expected benefits and encourage enterprises to innovate (Klemperer, 1990; Cohen, 2010). Due to the actual condition of relatively imperfect market mechanism and intellectual property protection system in China, the expected economic return and excess profit created by innovation activities are relatively low, and enterprises tend to rely more on the direct supplement of government subsidies for R\&D activities and the indirect financing obtained through the market signal effect exerted by government subsidies, which makes the spillover effect of government subsidies on enterprise R\&D and economic performance relatively stronger and more obvious in China. Therefore, this study proposes the following hypothesis:

H1: Government subsidies positively affect enterprise economic performance in China.

\subsection{Use of government subsidies and economic performance}

Generally, enterprises use subsidies to perform R\&D activities and expand their production capacity or treat the subsidies as current profits. Subsidies are intended to encourage innovative $\mathrm{R} \& \mathrm{D}$ activities and can usually effectively improve an enterprise's $\mathrm{R} \& \mathrm{D}$ input level (Carboni, 2017). In practice, however, some enterprises use subsidies for projects unrelated to $\mathrm{R} \& \mathrm{D}$ to generate economic benefits in the fastest and easiest way, especially when 
subsidy availability is low (Gelabert et al., 2009). Studies have indicated that subsidies have a crowding-out effect on $\mathrm{R} \& \mathrm{D}$ input and can result in production overcapacity (Bernini \& Pellegrini, 2011). Nevertheless, subsidies can positively affect economic performance regardless of whether they are used for $\mathrm{R} \& \mathrm{D}$ activities or to expand production capacity. If used for R\&D activities, subsidies directly produce economic benefits by increasing the level of innovation output, and indirectly raise more $\mathrm{R} \& \mathrm{D}$ funds through positive market signals (Geroski \& Machin, 2006). If used to expand production capacity, subsidies can help enterprises open markets, obtain greater market share, and gain competitive advantages (Tzelepis \& Skuras, 2006).

Moreover, enterprises usually use some of the available subsidies to invest in human resources, especially $\mathrm{R} \& \mathrm{D}$ training. Human resource training represents the "non-material capital" input, which is the capital reflected in the workers through training expenditure, such as their knowledge and skills, cultural and technological level and health status, etc. Human resource training is linked with personal freedom, does not transfer with the sale of products, and is formed through human capital investment. Training can improve the quality of the labor force, the working ability and technical level of workers, thus increasing labor productivity and ultimately promoting economic performance. Redding (1996) indicated that when economic equilibrium is attained at a low point, more R\&D input cannot significantly improve economic performance unless the human capital investment level is raised because of the complementary relationship between R\&D input and human capital investment. Furthermore, London et al. (2008) argued that human capital training is intended to boost innovation ability and equip the enterprise with requisite skills to apply new technologies. Some studies have shown that employees with more knowledge and higher skills are important resources and play a critical role in improving economic performance (Boselie et al., 2005). Using data of listed companies in Sri Lanka, Perera (2012) illustrated that the level of knowledge and skills affects enterprise performance and training can significantly improve performance. Therefore, this study proposes the following hypothesis:

H2: Enterprises use subsidies for R\&D input, expanding the production capacity for existing products, and human resource training, and all the three use patterns positively affect economic performance.

\section{Theoretical model}

Based on the above literature review and hypotheses, we can only know that the enterprises' different subsidy use patterns have impact on economic performance, but cannot know what factors affect the enterprise actual use of subsidies, which is quite essential when developing the empirical model to analyse the mechanisms of such effects. Therefore, we construct a theoretical model of government subsidies and enterprise behavioral responses to identify the factors that affect subsidy use.

The production function of enterprises is assumed to be a simple Cobb-Douglas production function:

$$
Y_{i t}=A_{i t} K_{i t}^{\alpha} L_{i t}^{1-\alpha},
$$

where: $Y_{i t}$ denotes the product output, $A_{i t}$ denotes the technological level, $K_{i t}$ and $L_{i t}$ denote 
the capital and labor inputs for manufacturing existing products, respectively, $\alpha$ denotes the output elasticity of capital (i.e., the rate of change in output arising from the change in capital input), $1-\alpha$ denotes the output elasticity of labor, $i$ denotes the $i$-th enterprise, and $t$ denotes the $t$-th year. Assume that the government grants subsidy $S_{i t}$ according to the capital input of the previous period for manufacturing existing products $K_{i t-1}$ is:

$$
S_{i t}=s K_{i t-1},
$$

where: $s$ denotes the fixed ratio of subsidies that are mainly used for three activities: R\&D input, expansion of production capacity for existing products, and human resource training. The enterprise determines the levels of $r_{i t}, K_{i t}$, and $L_{i t}$, and uses $r_{i t}$ for R\&D activities so that the technological level is changed as follows:

$$
A_{i t}=\rho_{i t} r_{i t}+A_{i t-1} \text {, }
$$

where: $\rho_{i t}$ denotes the success rate of $\mathrm{R} \& \mathrm{D}$. Accordingly, the enterprise can obtain a return from $\mathrm{R} \& \mathrm{D}, V\left(A_{i t}\right)$, at the end of each period. Additionally, the enterprise uses the remaining subsidies to expand the production capacity of existing products $\left(K_{i t}-K_{i t-1}\right)$ and to train human resource $m\left(L_{i t}-L_{i t-1}\right)$, where: $m$ denotes the unit cost of training. Thus, the government subsidies are obtained as follows:

$$
S_{i t}=s K_{i t-1}=r_{i t}+\left(K_{i t}-K_{i t-1}\right)+m\left(L_{i t}-L_{i t-1}\right) .
$$

It is assumed that all enterprises make profit-maximizing decisions. First, the enterprise determines the existing product capacity levels, $R \& D$ input, and input for training human resources; it then produces and sells the products and finally earns profit $U_{i t}$ :

$$
U_{i t}=\left(P_{i t}-C_{i t}\right) Y_{i t}+V\left(A_{i t}\right)-r_{i t}-C_{i t}^{K}\left(K_{i t}\right)-C_{i t}^{L}\left(L_{i t}\right),
$$

where: $C_{i t}^{L}\left(L_{i t}\right)$ denotes total cost of labor and $C_{i t}^{K}\left(K_{i t}\right)$ denotes total cost of capital (assuming that it is a variable with a linear relationship to capital). Then, the following equation is obtained:

$$
C_{i t}^{K}\left(K_{i t}\right)=C_{i t} \cdot K_{i t},
$$

where: $C_{i t}$ denotes the product's unit cost. Assume that $C_{i t}$ is a function of $K_{i t}, A_{i t}$, and $L_{i t}$. Then, the following equation is obtained:

$$
C_{i t}=C\left(K_{i t}, A_{i t}, L_{i t}\right)
$$

where: the product's unit cost is negatively correlated with the technological level and capital input but positively correlated with labor input, that is, $C_{i t}^{\prime}\left(K_{i t}\right)<0, C_{i t}^{\prime}\left(A_{i t}\right)<0$, and $C_{i t}^{\prime}\left(L_{i t}\right)>0 . P_{i t}$ denotes product price, which is assumed to be the mark-up on the product's unit cost. Then, the following equation is obtained:

$$
P_{i t}=(1+\delta) C_{i t},
$$

where: $\delta$ denotes profitability. Therefore, the optimization problem is summarized as follows. To maximize $U_{i t}$, the enterprise determines the levels of $r_{i t}, K_{i t}$, and $L_{i t}$ under the production capacity constraint $\left(Y_{i t} \leq K_{i t}\right)$ and finally makes the optimal behavioral decision $\left(U_{i t}^{*}=\left\{r_{i t}^{*}, K_{i t}^{*}, L_{i t}^{*}\right\}\right)$. 
To solve the optimization problem, the above equation is processed as follows:

$$
U_{i t}=\delta C_{i t}\left(\rho_{i t} r_{i t}+A_{i t-1}\right) K_{i t}^{\alpha} L_{i t}^{1-\alpha}+V\left(A_{i t}\right)-r_{i t}-C_{i t} K_{i t}-\mathrm{m} L_{i t}+m L_{i t-1} .
$$

According to the first order condition of the optimization problem, we obtain:

$$
\frac{\partial U_{i t}}{\partial r_{i t}}=\frac{\partial U_{i t}}{\partial K_{i t}}=\frac{\partial U_{i t}}{\partial L_{i t}}=0 .
$$

Considering the above constraint of production capacity, the optimal behavioral decision $\left(U_{i t}^{*}=\left\{r_{i t}^{*}, K_{i t}^{*}, L_{i t}^{*}\right\}\right)$ is finally determined as follows:

$$
\left\{\begin{array}{l}
K_{i t}^{*}=\left(\frac{1}{1-1 / \varepsilon_{i t}^{K C}}\right)\left(\frac{1}{1+1 / \delta}\right)\left(1-\frac{\varepsilon_{i t}^{K C}}{\alpha}\right) ; \\
L_{i t}^{*}=\left(\frac{1}{1-1 / \varepsilon_{i t}^{K C}}\right)\left(\frac{1}{1+1 / \delta}\right)\left(\frac{C_{i t}}{m}\right)\left(\frac{1}{\alpha}-1\right)\left[1+\left(\varepsilon_{i t}^{L C}-\varepsilon_{i t}^{K C}\right)\right] ; \\
r_{i t}^{*}=\left(\frac{C_{i t}}{\varphi}\right)\left(\frac{1}{1+1 / \delta}\right)\left(\frac{\varepsilon_{i t}^{K C}}{\alpha}\right)\left[\left(-\varepsilon_{i t}^{A C}\right)\left(\frac{\alpha-\varepsilon_{i t}^{K C}}{1-\varepsilon_{i t}^{K C}}\right)-1\right]-\frac{A_{i t-1}}{\rho_{i t}},
\end{array}\right.
$$

where: $\varepsilon_{i t}^{K C}$ denotes the capital cost elasticity, $\varepsilon_{i t}^{L C}$ denotes the labor cost elasticity, $\varepsilon_{i t}^{A C}$ denotes the technology cost elasticity $\left(\varepsilon_{i t}^{K C}, \varepsilon_{i t}^{L C}, \varepsilon_{i t}^{A C}<0\right.$, which reflects the percentage reduction in product cost when capital, labor, and technology, respectively, increase by $1 \%$ ), and $\varphi$ denotes the unit $R \& D$ operating expenses. $R \& D$ operating expenses is a part of $R \& D$ input, and directly associated with the R\&D of enterprises' goods or services and any intellectual property generated in the process of finding and creating new products or services (Frankenfield, 2020). R\&D operating expenses do not include the capitalized part of R\&D input, which is called $R \& D$ capital expenses (Kenton, 2021). The success rate of $R \& D$ is assumed to depend on the accumulation of previous technical levels, which can be expressed as $\rho_{i t}=\rho\left(A_{i t-1}\right)$; thus, $\frac{A_{i t-1}}{\rho_{i t}}$ in Eq. (13) is assumed to be a constant.

The results of Eq. (11) to (13) show that under the complex influence of multiple factors, enterprises usually allocate their subsidies to R\&D activities, expansion of production capacity for existing products, and human resource training with the goal of profit maximization. The specific allocations and uses of subsidies are affected to varying degrees by diverse factors, including profitability $(\delta)$, output elasticity of capital $(\alpha)$, unit cost for human resource training $(m)$, unit $\mathrm{R} \& \mathrm{D}$ operating expenses $(\varphi)$, unit cost of product $\left(C_{i t}\right)$, capital cost elasticity $\left(\varepsilon_{i t}^{K C}\right)$, labor cost elasticity $\left(\varepsilon_{i t}^{L C}\right)$, and technology cost elasticity $\left(\varepsilon_{i t}^{A C}\right)$.

Based on these preliminarily identified factors, empirical analysis needs to be further conducted to reveal specific influencing mechanisms, and several key factors are selected in the empirical model. First, both profitability $(\delta)$ and capital output elasticity $(\alpha)$ can be directly measured by statistical data and controlled. Second, despite no direct data source for the three elasticity variables (i.e., $\varepsilon_{i t}^{K C}, \varepsilon_{i t}^{L C}$, and $\varepsilon_{i t}^{A C}$ ), these depend somewhat on the cost factors that are relatively easy to measure: unit cost for human resource training $(m)$, unit R\&D operating expenses $(\varphi)$, and unit cost of product $\left(C_{i t}\right)$. Moreover, due to the high correlation, if the above elasticity variables and cost variables are all included in the empirical model, 
the problem of multicollinearity may exist. Accordingly, we create two proportion variables (the proportion of cost for human resource training to product cost and the proportion of R\&D operating expenses to product cost) in the empirical model and investigate their roles in the decision-making process, that is, whether they affect the performance of enterprises by regulating the actual use of subsidies in different activities. The reason for calculating the ratio variables is that, since unit $R \& D$ operating expenses, unit cost for human resource training, and unit cost of product are all identified as the possible influence mechanism factors, the construction of the ratio variables of $R \& D$ operating expenses to product cost and cost for human resource training to product cost can not only test these three factors at the same time, but also avoid the problem of lacking the data of product quantity. The theoretical framework of the present study is constructed (see Figure 1).

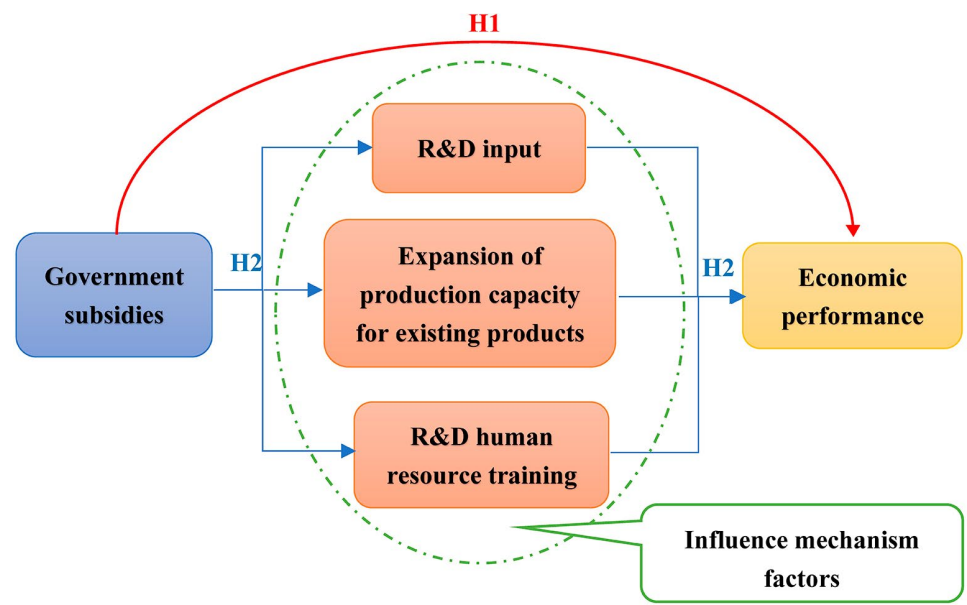

Note: The influence mechanism factors are the factors affecting enterprises' subsidy use which are identified from the results of theoretical model, including profitability $(\delta)$; output elasticity of capital $(\alpha)$; unit cost for human resource training $(m)$; unit R\&D operating expenses $(\varphi)$; unit cost of product $\left(C_{i t}\right)$; capital cost elasticity $\left(\varepsilon_{i t}^{K C}\right)$; labor cost elasticity $\left(\varepsilon_{i t}^{L C}\right)$; and technology cost elasticity $\left(\varepsilon_{i t}^{A C}\right)$.

Figure 1. Theoretical framework

\section{Empirical model}

Based on enterprise-level data, the following regression models are developed:

$$
\begin{aligned}
& \text { lnebit }_{i t}=\alpha_{1} \ln r d_{i t}+\alpha_{2} \operatorname{lncapexp}_{i t}+\alpha_{3} \operatorname{lnh} c_{i t}+\alpha_{4} \operatorname{lngov_{it-1}}+\alpha_{5} l c_{i t}+\alpha_{6} r d c_{i t}+ \\
& \alpha_{7} Z_{i t}+\alpha_{8} \text { Lindustry }_{i}+\alpha_{9} \sum \text { province }_{i}+\alpha_{10} \sum \text { year }_{i}+\alpha_{0 i}+\mu_{i t} ; \\
& \text { lnebit }_{i t}=\beta_{1}{\ln r d_{i t}}+\beta_{2} \operatorname{lncapexp}_{i t}+\beta_{3} \operatorname{lnh} c_{i t}+\beta_{4} \operatorname{lngov}_{i t-1}+\beta_{5} l c_{i t}+ \\
& \beta_{6} r d c_{i t}+\beta_{7} \ln r d_{i t}{ }^{*} N+\beta_{8} \operatorname{lncapexp}{ }_{i t}{ }^{*} N+\beta_{9} \operatorname{lnh} c_{i t}{ }^{*} N+\beta_{10} Z_{i t}+ \\
& \beta_{11} \text { Lindustry }_{i}+\beta_{12} \sum \text { province }_{i}+\beta_{13} \sum \text { year }_{i}+\beta_{0 i}+\mu_{i t} \text {, }
\end{aligned}
$$

where: Inebit denotes economic performance; ln $r d$ denotes R\&D input; lncapexp denotes expansion of production capacity for existing products; $\ln h c$ denotes human resource train- 
ing; lngov denotes government subsidy; $l c$ denotes the proportion of cost for human resource training to product cost (called "proportion of cost for human resource training" for short); $r d c$ denotes the proportion of R\&D operating expenses to product cost (called "proportion of R\&D operating expenses" for short); $N$ denotes $r d c_{i t}$ in Eq. (15) and $l c_{i t}$ in Eq. (16); $Z$ denotes all control variables, including technical level, profitability, capital profitability, growth ability, financial risk, short-term solvency, operating ability, enterprise age, enterprise size, equity concentration, and top management shareholding; $\sum$ industry $_{i}, \sum_{\text {province }_{i}}$ and $\sum$ year $r_{i}$ denote the dummy variables of industry, province and year, respectively; $\alpha_{1}, \ldots, \alpha_{10}$ and $\beta_{1}, \ldots, \beta_{13}$ denote regression coefficients; $\alpha_{0 i}$ and $\beta_{0 i}$ denote constant terms; $\mu$ denotes the random error term; $i$ denotes the $i$-th enterprise; and $t$ denotes the $t$-th year.

Eq. (15) and (16) are respectively used to test whether the decision-making process of enterprises, which aim to maximize profits, is moderated by two variables, the proportion of cost for human resource training and the proportion of $\mathrm{R} \& \mathrm{D}$ operating expenses, when enterprises use the available subsidies for different activities ( $\& \mathrm{D}$, expansion of production capacity, and training human resource). The intent is to examine the specific influencing mechanisms involved. Eq. (14) is the benchmark model.

Ordinary least squares (OLS) is most commonly used to analyze the effect of independent variables on the conditional expectation of dependent variables. However, OLS results can only reflect the effect of independent variables on the mean value of dependent variables. The impact of independent variables on the median and each quantile of dependent variables cannot be fully presented. Moreover, OLS requires that the random error term must satisfy rigorous assumptions.

Quantile regression (QR) is a linear regression method for fitting explanatory variables based on different conditional distributions of the explained variables, which is an improvement and extension of mean regression. Powell and Wagner (2014) further proposed the panel QR approach, which can analyze the influence among variables at different quantiles in the conditional distribution of explained variables, controlling both the individual and time effects. Therefore, after conducting OLS regression, this study further uses panel QR to test for differences among enterprises with heterogeneous economic performance.

\section{Description of variables and data source}

\subsection{Explained variable}

Extant studies usually use return on equity (Jin et al., 2018) and net profit (Hogendoorn et al., 2019) to measure economic performance (lnebit). This study uses earnings before interest and taxes (EBIT) to measure economic performance for the following reasons. Given that the influence of enterprise size on dependent variables is to be separately investigated in the control variables, we need to avoid including asset factors (e.g., enterprise size) in the variable of economic performance, which renders indicators such as return on equity unsuitable for this study. Moreover, preferential tax is another instrument used to encourage enterprises to undertake sci-tech innovation. However, when granting subsidies, governments rarely refer to enterprises' net profits, which exclude interest and taxes. Therefore, EBIT and natural logarithms are used to reduce data volatility. 


\subsection{Explanatory variables}

Some studies have used the subsidy to operating revenue ratio as a measure (Jin et al., 2018) while others have used a subsidy dummy variable (Tzelepis \& Skuras, 2006). As this study uses some variables directly composed of operating revenue as control variables, the use of the subsidy ratio may create multicollinearity and reduce the accuracy of the empirical results. Additionally, there is always a lag from obtaining subsidies to using the funds and then to realizing economic benefits. Therefore, referring to Gelabert's et al. (2009) approach, we measure subsidies by using the natural logarithm of one plus government subsidies obtained by enterprises with a one-year lag.

The explanatory variables of $\mathrm{R} \& \mathrm{D}$ input $(\ln r d)$, expansion of production capacity for existing products $(\operatorname{lncapexp})$, and human resource training $(\ln h c)$ are used to indicate the three subsidy use patterns. In the Chinese context, it is possible to distinguish between R\&D input and R\&D human resource training. Unlike most developed countries, China's official statistics adopts the standard that is not in line with international standards for collecting and reporting R\&D inputs. For example, the official published data of R\&D input in China does not include salaries and training fees for university faculty members and postdocs, which is a significant component of R\&D expenditure in other countries (Sun \& Cao, 2016). Therefore, the three variables of subsidy use patterns are respectively measured in terms of the natural logarithm of the R\&D input (Gelabert et al., 2009; Jin et al., 2018), net cash of long-term assets (including building, purchasing, and disposing of fixed and intangible assets to produce existing products), and cash paid to employees and for employee training, as disclosed in financial statements.

\subsection{Moderating variables}

To test the mechanism through which economic performance is influenced by subsidy use patterns, the following two moderating variables are selected according to the theoretical model results: 1) proportion of cost for human resource training $(l c)$ measured by the ratio of the cost of training human resource to product cost; and 2) proportion of R\&D operating expenses $(r d c)$ measured by the ratio of the R\&D operating expenses to product cost.

\subsection{Control variables}

Several control variables are introduced based on existing research (Chen \& Huang, 2011; Jin et al., 2018). Technical level (lnpat) is measured in terms of the cumulative number of patents obtained by the enterprise and is measured by the natural logarithm to reduce data volatility. Profitability (profitp) is measured in terms of operating profit ratio used to control the profitability $(\delta)$ in the theoretical model. Capital profitability (lneps) is measured by the natural logarithm of basic earnings per share used to control the output elasticity of capital $(\alpha)$ in the theoretical model. Growth ability (growth), financial risk (lev), short-term solvency (cash), and operating ability (turnover) are respectively measured by growth rate of operating revenue, asset-liability ratio, cash ratio, and total asset turnover. Enterprise age (age) and size (lnasset) are respectively measured by the years since the enterprise's establishment and the natural logarithm of its total assets. Equity concentration (concen) is measured by the sum of 
the shareholding ratios of the 10 major shareholders. Management shareholding (nmshare) is measured in terms of the natural logarithm of the number of shares held by top management. The dummy variables of industries (industry), provinces (province) and years (year) are introduced.

\subsection{Data source}

Using China's A-share listed companies as the sample and the research period from 2007 to 2017, 3,565 preliminarily selected enterprises are obtained. We use 2007 as the starting year for two reasons. First, the "National Program for Long- and Medium-term Scientific and Technological Development (2006 to 2020)" was enacted in 2006. Considering the lagged effect of such policies, it is more appropriate to choose 2007 as the starting year of research. Second, the data of some economic indicators are more complete for 2007 onwards.

Enterprises with severely incomplete data disclosure are excluded from the study. For enterprises with missing data in one or two years, linear interpolation is performed to ensure a large enough number of observations. For enterprises with abnormal data in certain years, winsorization is conducted for the quantiles below $1 \%$ and above $99 \%$ of continuous variables to avoid the impact of outliers. After data processing, we obtain a final sample of 3,491 enterprises across 11 years. Variables susceptible to price levels are deflated with 1999 as the base period. The data used in this study is obtained from the CSMAR database, WIND database, financial statements, and the China Statistical Yearbooks.

Table 1. Descriptive statistics of main variables (source: authors' calculation)

\begin{tabular}{|l|c|c|c|c|}
\hline \multicolumn{1}{|c|}{ Variable } & Mean & Standard deviation & Min & Max \\
\hline lnebit & 8.330 & 1.532 & -0.956 & 15.906 \\
\hline lnrd & 6.832 & 1.473 & 0.003 & 14.250 \\
\hline lncapexp & 7.639 & 2.006 & -2.858 & 15.978 \\
\hline lnhc & 8.147 & 1.450 & 0.757 & 14.838 \\
\hline lngov & 5.129 & 1.709 & 0.006 & 14.334 \\
\hline lc & 12.308 & 45.138 & 0 & 1568.660 \\
\hline rdc & 8.570 & 41.840 & 0 & 1483.977 \\
\hline lnpat & 3.570 & 1.971 & 0 & 9.959 \\
\hline profitp & -0.687 & 68.727 & -9533.092 & 552.838 \\
\hline lneps & 0.073 & 0.147 & -8.163 & 1.436 \\
\hline growth & 4.428 & 33.612 & -665.310 & 5941.550 \\
\hline lev & 2.089 & 78.520 & -342.769 & 9607.304 \\
\hline cash & 1.104 & 3.181 & -5.055 & 167.544 \\
\hline turnover & 0.637 & 0.562 & 0 & 11.416 \\
\hline age & 16.056 & 5.448 & 0 & 67.000 \\
\hline lnasset & 11.234 & 1.502 & 0 & 19.983 \\
\hline concen & 58.152 & 16.129 & 1.310 & 101.160 \\
\hline lnmshare & 3.338 & 3.605 & 0 & 12.432 \\
\hline
\end{tabular}


Before regression analysis, four methods of unit root test are conducted-LLC test, IPS test, ADF-Fisher test, and PP-Fisher test-to ensure stationarity of data and robustness of the results. All variables pass the four tests and can therefore be used for analysis. Descriptive statistics of the main variables are reported in Table 1 . It can be seen from the mean values of the three variables of subsidy use patterns that human resource training is the highest (8.147), expansion of production capacity for existing products is second (7.639), and R\&D input is the smallest (6.832). Moreover, the two moderating variables $(r d c$ and $l c$ ) show relatively large volatility among different enterprises, thus confirming the necessity of heterogeneity test to some extent. To avoid the potential impact of some extreme values, we further standardized all the variables for the regression analysis.

\section{Empirical results and analysis}

We test Eqs (14) to (16) to analyze whether the process in which the three subsidy use patterns affect economic performance is moderated by certain factors (i.e., proportion of R\&D operating expenses and proportion of cost for human resource training). OLS regression is used to analyze the full sample. Panel QR is then performed to further investigate whether any differences exist in the analysis results among enterprises in different quantiles of economic performance.

\subsection{OLS regression results}

Column 2 of Table 2 presents the OLS regression results of the benchmark model Eq. (14). First, the total amount of subsidies significantly and positively affects economic performance at the $1 \%$ level, corroborating hypothesis H1. Second, the subsidies used for both expansion of production capacity for existing products and human resource training positively affect economic performance at the $1 \%$ significance level (coefficients: 0.057 and 0.216 , respectively), while the impact of the subsidies used for R\&D input on economic performance is insignificant, partially supporting hypothesis H2. Although the total amount of subsidies effectively improves the economic performance, the part of subsidies which were actually used for R\&D activities by enterprises has no obvious promoting effect on their economic performance. The positive impact of R\&D input on economic performance should be significant from economic intuition, but the result here is insignificant. The possible reasons are as follows: first, since R\&D investment may reduce enterprises' expectations of short-term economic benefits to some extent, it will weaken the enthusiasm of some enterprises to use subsidies for R\&D activities, but prompt enterprises to use a large part of the subsidies on other activities, such as expansion of production capacity for existing products, which ultimately led to more significant effect of this activity on improving economic performance; second, we also noticed that proportion of R\&D operating expenses and proportion of cost for human resource training have no significant negative impact on economic performance. However, based on the analysis of the above theoretical model, as well as the assumptions of the moderating role of certain factors, this result also violates the economic intuition. For this reason, we further analyze the possible moderating effects of these two variables by combing the estimation results of Eqs (15) and (16), which will help to provide a reasonable explanation for the above results of the benchmark model Eq. (14). 
Table 2. Results of OLS regression

\begin{tabular}{|c|c|c|c|}
\hline & (14) & (15) & (16) \\
\hline & lnebit & lnebit & lnebit \\
\hline $\ln r d$ & $\begin{array}{c}0.014 \\
(0.026)\end{array}$ & $\begin{array}{c}0.196^{* * *} \\
(0.047)\end{array}$ & $\begin{array}{l}-0.004 \\
(0.148)\end{array}$ \\
\hline lncapexp & $\begin{array}{c}0.057^{* * *} \\
(0.018)\end{array}$ & $\begin{array}{l}0.038^{* *} \\
(0.018)\end{array}$ & $\begin{array}{l}-0.071 \\
(0.067)\end{array}$ \\
\hline $\operatorname{lnh} c$ & $\begin{array}{c}0.216^{* * *} \\
(0.041)\end{array}$ & $\begin{array}{c}0.144^{* * *} \\
(0.044)\end{array}$ & $\begin{array}{c}0.481^{\star * *} \\
(0.165)\end{array}$ \\
\hline $\operatorname{lngov}$ & $\begin{array}{c}0.043^{* * *} \\
(0.015)\end{array}$ & $\begin{array}{c}0.041^{\star * *} \\
(0.014)\end{array}$ & $\begin{array}{c}0.042^{* * *} \\
(0.014)\end{array}$ \\
\hline$r d c$ & $\begin{array}{l}0.085 \\
(0.11)\end{array}$ & $\begin{array}{c}-0.696^{* * *} \\
(0.195)\end{array}$ & $\begin{array}{c}0.142 \\
(0.138)\end{array}$ \\
\hline lc & $\begin{array}{l}-1.526 \\
(1.925)\end{array}$ & $\begin{array}{l}-2.802 \\
(2.787)\end{array}$ & $\begin{array}{c}-10.697^{* * *} \\
(3.817)\end{array}$ \\
\hline profitp & $\begin{array}{c}164.901^{* * *} \\
(14.598)\end{array}$ & $\begin{array}{c}177.883^{* * *} \\
(15.361)\end{array}$ & $\begin{array}{c}171.645^{* * *} \\
(16.058)\end{array}$ \\
\hline lneps & $\begin{array}{c}0.318^{* * *} \\
(0.04)\end{array}$ & $\begin{array}{c}0.284^{* * *} \\
(0.038)\end{array}$ & $\begin{array}{c}0.328^{* * *} \\
(0.039)\end{array}$ \\
\hline lnasset & $\begin{array}{c}0.672^{* * *} \\
(0.048)\end{array}$ & $\begin{array}{c}0.607^{* * *} \\
(0.049)\end{array}$ & $\begin{array}{c}0.639^{* * *} \\
(0.047)\end{array}$ \\
\hline growth & $\begin{array}{c}0.056 \\
(0.102)\end{array}$ & $\begin{array}{c}0.186 \\
(0.121)\end{array}$ & $\begin{array}{c}-0.02 \\
(0.108)\end{array}$ \\
\hline lev & $\begin{array}{c}-6.125^{\star * \star} \\
(0.846)\end{array}$ & $\begin{array}{c}-6.53^{* * *} \\
(0.899)\end{array}$ & $\begin{array}{c}-6.23^{* * *} \\
(0.836)\end{array}$ \\
\hline cash & $\begin{array}{c}-0.041^{*} \\
(0.021)\end{array}$ & $\begin{array}{l}-0.021 \\
(0.016)\end{array}$ & $\begin{array}{c}-0.036^{*} \\
(0.02)\end{array}$ \\
\hline turnover & $\begin{array}{c}0.103^{* * *} \\
(0.039)\end{array}$ & $\begin{array}{c}0.085^{* * *} \\
(0.033)\end{array}$ & $\begin{array}{l}0.092^{\star *} \\
(0.036)\end{array}$ \\
\hline concen & $\begin{array}{l}-0.014 \\
(0.015)\end{array}$ & $\begin{array}{l}-0.012 \\
(0.015)\end{array}$ & $\begin{array}{l}-0.017 \\
(0.015)\end{array}$ \\
\hline Inmshare & $\begin{array}{c}0.016 \\
(0.012)\end{array}$ & $\begin{array}{c}0.014 \\
(0.011)\end{array}$ & $\begin{array}{c}0.01 \\
(0.012)\end{array}$ \\
\hline $\ln r d^{*} r d c$ & & $\begin{array}{l}0.97^{\star * *} \\
(0.214)\end{array}$ & \\
\hline 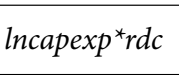 & & $\begin{array}{l}-0.093 \\
(0.119) \\
\end{array}$ & \\
\hline $\operatorname{lnh} c^{*} r d c$ & & $\begin{array}{c}-0.399^{* *} \\
(0.176)\end{array}$ & \\
\hline $\ln r d^{*} l c$ & & & $\begin{array}{l}-0.422 \\
(6.069) \\
\end{array}$ \\
\hline $\operatorname{lncapexp}{ }^{*} l c$ & & & $\begin{array}{l}-5.46^{*} \\
(3.058)\end{array}$ \\
\hline $\operatorname{lnh} c^{\star} l c$ & & & $\begin{array}{l}10.067 \\
(6.817)\end{array}$ \\
\hline industry & yes & yes & yes \\
\hline province & yes & yes & yes \\
\hline year & yes & yes & yes \\
\hline Constant & $\begin{array}{c}-2.037^{\star * *} \\
(0.174)\end{array}$ & $\begin{array}{c}-2.3^{* * *} \\
(0.2)\end{array}$ & $\begin{array}{c}-2.312^{* * *} \\
(0.225)\end{array}$ \\
\hline No. of Obs. & 1317 & 1317 & 1317 \\
\hline$R$-squared & 0.900 & 0.908 & 0.903 \\
\hline
\end{tabular}

Note: Clustered robust standard errors are in parentheses. ${ }^{* * *},{ }^{* *}$ and ${ }^{\star}$ denote statistical significance at $1 \%, 5 \%$ and $10 \%$ levels, respectively. 
Columns 3 of Table 2 presents the results of the moderating effect of the proportion of $\mathrm{R} \& \mathrm{D}$ operating expenses on the ways in which subsidy use patterns affect economic performance. First, the coefficient of the interaction term between $R \& D$ input and the proportion of $R \& D$ operating expenses is significantly positive at the $1 \%$ level, which means that the promotion effect of R\&D input on economic performance is greater in companies with a higher proportion of $\mathrm{R} \& \mathrm{D}$ operating expenses than those with relatively low proportion of $\mathrm{R} \& \mathrm{D}$ operating expenses. Second, the coefficient of the interaction term between human resource training and the proportion of R\&D operating expenses is significantly negative at the $5 \%$ level, which shows that the promotion effect of human resource training on economic performance is smaller in companies with a higher proportion of $\mathrm{R} \& \mathrm{D}$ operating expenses than those with relatively low proportion of $R \& D$ operating expenses. Therefore, the proportion of $R \& D$ operating expenses plays a significant moderating role in $R \& D$ activities and human resource training affecting economic performance, indicating that the proportion of $\mathrm{R} \& \mathrm{D}$ operating expenses is a critical consideration in decision-making on subsidy use. The reason is that the proportion of $\mathrm{R} \& \mathrm{D}$ operating expenses directly affects enterprises' economic profit of the current period, which will affect enterprises' behavior decision of using government subsidies, especially significant for the activities taking a long period to realize economic returns (i.e. $\mathrm{R} \& \mathrm{D}$ activities and human resource training). Moreover, after introducing the interaction terms, the subsidies used for $\mathrm{R} \& \mathrm{D}$ input shows a significant positive effect on economic performance, and the proportion of $R \& D$ operating expenses shows a significant negative effect on economic performance, which verify our economic intuition, and indicate that the moderating role played by the proportion of $R \& D$ operating expenses is critical. In the benchmark model, the positive effect of $R \& D$ input and the negative effect of the proportion of $R \& D$ operating expenses on economic performance are concealed somewhat. Since the characteristics of daily production and operation activities of enterprises in different industries are quite different, the degree of their dependence on $\mathrm{R} \& \mathrm{D}$ activities is also different, which may obscure the total effect to some extent and lead to insignificant results in the benchmark model. Specifically, for enterprises in technology-intensive industries such as high-tech industries, $\mathrm{R} \& \mathrm{D}$ activities account for a large proportion of their daily production and operation activities, so $\mathrm{R} \& \mathrm{D}$ operating expenses account for a greater proportion of their total operating cost, and correspondingly, the proportion of cost for human resource training is relatively low. The higher the proportion of a company's R\&D operating expenses, the greater the dependence of the enterprise on creating economic benefits through R\&D activities, and the less the dependence on other activities including human resource training. The above results also illustrate the necessity to further testing the heterogeneity of the regression results through panel quantile regression. Third, the coefficient of the interaction term between expansion of production capacity for existing products and the proportion of $\mathrm{R} \& \mathrm{D}$ operating expenses is not significant, indicating that the proportion of R\&D operating expenses has no significant moderating impact on the relationship between expansion of production capacity for existing products and economic performance.

Columns 4 of Table 2 reports the results of the moderating effect of the proportion of cost for human resource training. First, the interaction items of the proportion of cost for human resource training and two variables, R\&D input and human resource training, are not significant. This implies that the impact of $R \& D$ input and human resource training on 
economic performance is not significantly moderated by the proportion of cost for human resource training. Second, the coefficient of the interaction term between expansion of production capacity for existing products and the proportion of cost for human resource training is significantly negative at the $10 \%$ level, implying that the promotion effect of expansion of production capacity for existing products on economic performance is smaller in companies with a higher proportion of cost for human resource training than those with relatively low proportion of cost for human resource training. In fact, human resource training has an indirect impact on the economic performance of enterprises, and there is a high degree of uncertainty as to whether and to what extent it can have a positive impact. The reason is that the final result of employee training not only depends on the level of training funds invested by the enterprises, but also depends to a large extent on the characteristics of the R\&D personnel, their degree of efforts, and their ability to absorb and transform new knowledge and technologies, etc. Moreover, after introducing the interaction terms, the proportion of cost for human resource training in Eq. (16) has a significant negative effect on economic performance, which means that a higher cost of training $R \& D$ personnel is detrimental to the improvement of economic performance. Therefore, for enterprises that pay more attention to training R\&D personnel and invest more in such activities, although the cost of human resource training tends to account for a greater proportion of their total operating cost, their subsidies used for human resource training and R\&D activities may not necessarily be shown to have a significant promotion effect on the economic performance. However, correspondingly, the subsidies available for such enterprises to expand the capacity of existing products will be reduced, so this part of the funds will naturally have a relatively low promotion effect on economic performance.

\subsection{Results of panel quantile regression}

To assess whether the conclusions significantly differ among enterprises with heterogeneous economic performance, this study uses panel QR for further testing and selects nine quantiles $(0.1,0.2,0.3 \ldots 0.9)$ to ensure the comprehensiveness of the results (see Table 3 ). The results indeed differ among enterprises with different levels of economic performance.

The results shown in Panel 1 of Table 3 reveal the following. First, the positive effect of $\mathrm{R} \& \mathrm{D}$ input on economic performance are not significant in all quantiles with the coefficients decreasing as the quantiles increase. This is possibly because enterprises with low economic performances are usually start-ups with relatively unsophisticated technical levels; if they use available subsidies for R\&D activities, their overall production efficiencies would improve thereby creating greater economic benefits. Enterprises with relatively strong economic performances usually possess more mature production technologies and more complete infrastructure. They use subsidies for R\&D technological upgrades that generally show an impact on profits in the long term, while the short-term impact is not significant.

Second, expansion of production capacity for existing products has no significant effect on economic performance in all quantiles with the coefficients decreasing from positive to negative as the quantiles increase. The results imply that for all enterprises, using subsidies to expand production capacity of existing products does not significantly improve economic returns. This is possibly because when a product is newly launched, its profitability is high 
Table 3. Results of panel quantile regression

\begin{tabular}{|c|c|c|c|c|c|c|c|c|c|}
\hline & \multicolumn{9}{|c|}{ Panel quantile regression (lnebit) } \\
\hline & 0.1 & 0.2 & 0.3 & 0.4 & 0.5 & 0.6 & 0.7 & 0.8 & 0.9 \\
\hline \multicolumn{10}{|c|}{ Panel 1: Effects of three use patterns of government subsidies on economic performance (14) } \\
\hline $\ln r d$ & $\begin{array}{c}0.134 \\
(0.694)\end{array}$ & $\begin{array}{c}0.129 \\
(0.562)\end{array}$ & $\begin{array}{c}0.124 \\
(0.446)\end{array}$ & $\begin{array}{c}0.119 \\
(0.339)\end{array}$ & $\begin{array}{c}0.114 \\
(0.228)\end{array}$ & $\begin{array}{c}0.109 \\
(0.131)\end{array}$ & $\begin{array}{c}0.105 \\
(0.094)\end{array}$ & $\begin{array}{c}0.102 \\
(0.117)\end{array}$ & $\begin{array}{c}0.097 \\
(0.206)\end{array}$ \\
\hline lncapexp & $\begin{array}{c}0.026 \\
(0.354)\end{array}$ & $\begin{array}{c}0.02 \\
(0.287)\end{array}$ & $\begin{array}{c}0.016 \\
(0.228)\end{array}$ & $\begin{array}{c}0.012 \\
(0.173)\end{array}$ & $\begin{array}{c}0.007 \\
(0.116)\end{array}$ & $\begin{array}{c}0.003 \\
(0.067)\end{array}$ & $\begin{array}{l}-0.001 \\
(0.048)\end{array}$ & $\begin{array}{c}-0.004 \\
(0.06)\end{array}$ & $\begin{array}{l}-0.008 \\
(0.105)\end{array}$ \\
\hline $\operatorname{lnh} c$ & $\begin{array}{c}0.457 \\
(1.171) \\
\end{array}$ & $\begin{array}{c}0.424 \\
(0.949) \\
\end{array}$ & $\begin{array}{c}0.395 \\
(0.752) \\
\end{array}$ & $\begin{array}{c}0.368 \\
(0.572) \\
\end{array}$ & $\begin{array}{c}0.339 \\
(0.384) \\
\end{array}$ & $\begin{array}{c}0.311 \\
(0.222) \\
\end{array}$ & $\begin{array}{c}0.29^{*} \\
(0.159) \\
\end{array}$ & $\begin{array}{c}0.271 \\
(0.198) \\
\end{array}$ & $\begin{array}{c}0.244 \\
(0.348)\end{array}$ \\
\hline \multicolumn{10}{|c|}{ Panel 2: Moderating effect of the proportion of R\&D operating expenses (15) } \\
\hline$r d c$ & $\begin{array}{l}-1.097 \\
(0.857)\end{array}$ & $\begin{array}{l}-1.07^{\star \star} \\
(0.544)\end{array}$ & $\begin{array}{l}-1.051^{\star} \\
(0.637)\end{array}$ & $\begin{array}{l}-1.029 \\
(0.967)\end{array}$ & $\begin{array}{l}-1.008 \\
(1.383)\end{array}$ & $\begin{array}{l}-0.987 \\
(1.822)\end{array}$ & $\begin{array}{l}-0.971 \\
(2.153)\end{array}$ & $\begin{array}{l}-0.957 \\
(2.459)\end{array}$ & $\begin{array}{l}-0.937 \\
(2.878)\end{array}$ \\
\hline $\ln r d^{*} r d c$ & $\begin{array}{l}1.293^{*} \\
(0.729)\end{array}$ & $\begin{array}{c}1.228^{\star * *} \\
(0.464)\end{array}$ & $\begin{array}{l}1.18^{\star *} \\
(0.542)\end{array}$ & $\begin{array}{c}1.129 \\
(0.823)\end{array}$ & $\begin{array}{c}1.076 \\
(1.177)\end{array}$ & $\begin{array}{c}1.024 \\
(1.551)\end{array}$ & $\begin{array}{c}0.986 \\
(1.832)\end{array}$ & $\begin{array}{c}0.95 \\
(2.093)\end{array}$ & $\begin{array}{c}0.903 \\
(2.448)\end{array}$ \\
\hline $\operatorname{lncapexp}{ }^{*} r d c$ & $\begin{array}{c}0.084 \\
(0.493)\end{array}$ & $\begin{array}{c}0.087 \\
(0.313)\end{array}$ & $\begin{array}{c}0.09 \\
(0.367) \\
\end{array}$ & $\begin{array}{c}0.092 \\
(0.557)\end{array}$ & $\begin{array}{c}0.095 \\
(0.796)\end{array}$ & $\begin{array}{c}0.097 \\
(1.049)\end{array}$ & $\begin{array}{c}0.099 \\
(1.239)\end{array}$ & $\begin{array}{c}0.101 \\
(1.415)\end{array}$ & $\begin{array}{c}0.103 \\
(1.656)\end{array}$ \\
\hline $\operatorname{lnh} c^{*} r d c$ & $\begin{array}{l}-0.993 \\
(0.686)\end{array}$ & $\begin{array}{c}-0.913^{\star *} \\
(0.436)\end{array}$ & $\begin{array}{c}-0.853^{\star} \\
(0.51)\end{array}$ & $\begin{array}{l}-0.789 \\
(0.775) \\
\end{array}$ & $\begin{array}{l}-0.723 \\
(1.107) \\
\end{array}$ & $\begin{array}{l}-0.658 \\
(1.458) \\
\end{array}$ & $\begin{array}{l}-0.611 \\
(1.723)\end{array}$ & $\begin{array}{l}-0.567 \\
(1.968) \\
\end{array}$ & $\begin{array}{l}-0.507 \\
(2.303)\end{array}$ \\
\hline \multicolumn{10}{|c|}{ Panel 3: Moderating effect of the proportion of cost for human resource training (16) } \\
\hline lc & $\begin{array}{c}-17.39 \\
(12.127)\end{array}$ & $\begin{array}{c}-15.604 \\
(9.61)\end{array}$ & $\begin{array}{c}-14.293^{\star} \\
(7.899)\end{array}$ & $\begin{array}{l}-12.953^{\star *} \\
(6.395)\end{array}$ & $\begin{array}{c}-11.281^{\star \star} \\
(5.185)\end{array}$ & $\begin{array}{l}-9.927^{\star} \\
(5.081)\end{array}$ & $\begin{array}{l}-8.815 \\
(5.649)\end{array}$ & $\begin{array}{l}-7.875 \\
(6.486)\end{array}$ & $\begin{array}{c}-6.511 \\
(8.05)\end{array}$ \\
\hline $\ln r d^{*} l c$ & $\begin{array}{c}-4.674 \\
(19.591)\end{array}$ & $\begin{array}{c}-3.811 \\
(15.522)\end{array}$ & $\begin{array}{c}-3.178 \\
(12.754)\end{array}$ & $\begin{array}{c}-2.53 \\
(10.312)\end{array}$ & $\begin{array}{l}-1.722 \\
(8.349)\end{array}$ & $\begin{array}{l}-1.067 \\
(8.192)\end{array}$ & $\begin{array}{c}-0.53 \\
(9.121)\end{array}$ & $\begin{array}{c}-0.075 \\
(10.477)\end{array}$ & $\begin{array}{c}0.584 \\
(13)\end{array}$ \\
\hline lncapexp ${ }^{*} l c$ & $\begin{array}{l}-10.284 \\
(10.301)\end{array}$ & \begin{tabular}{|l|}
-9.398 \\
$(8.162)$
\end{tabular} & $\begin{array}{l}-8.749 \\
(6.707)\end{array}$ & $\begin{array}{l}-8.085 \\
(5.425)\end{array}$ & $\begin{array}{l}-7.256^{*} \\
(4.395)\end{array}$ & $\begin{array}{l}-6.585 \\
(4.31)\end{array}$ & $\begin{array}{l}-6.034 \\
(4.797)\end{array}$ & $\begin{array}{l}-5.568 \\
(5.509)\end{array}$ & $\begin{array}{l}-4.892 \\
(6.837)\end{array}$ \\
\hline $\operatorname{lnh} c^{\star} l c$ & $\begin{array}{l}17.342 \\
(22.47)\end{array}$ & $\begin{array}{c}15.284 \\
(17.803)\end{array}$ & $\begin{array}{c}13.774 \\
(14.629)\end{array}$ & $\begin{array}{c}12.23 \\
(11.831)\end{array}$ & $\begin{array}{l}10.304 \\
(9.582)\end{array}$ & $\begin{array}{c}8.744 \\
(9.399)\end{array}$ & $\begin{array}{c}7.464 \\
(10.462)\end{array}$ & $\begin{array}{c}6.38 \\
(12.016)\end{array}$ & $\begin{array}{c}4.809 \\
(14.912)\end{array}$ \\
\hline
\end{tabular}

Note: Clustered robust standard errors are in parentheses. ${ }^{* *},{ }^{* *}$ and ${ }^{*}$ denote statistical significance at $1 \%, 5 \%$ and $10 \%$ levels, respectively. Due to the limited space, only the results of core variables are presented here.

for a certain period; however, the high profitability also attracts competitors to conduct R\&D and produce similar goods, thereby maturing the production technologies and greatly reducing profit margins.

Third, human resource training has a positive effect on economic performance, significant only at 0.7 quantile with the coefficient decreasing as the quantiles increase. A possible reason is that enterprises with poor economic performance can rarely attract high-caliber technological personnel. However, they generally need to recruit large numbers of technological personnel and improve the overall technical level of their R\&D teams, in which subsidies play a crucial role. Enterprises with strong economic performances can usually attract high-caliber personnel through high salaries. They use subsidies to cultivate talent mostly in innovative R\&D areas of high uncertainty and high risk that need longer periods to generate significant impacts. 
The results shown in Panel 2 of Table 3 reveal the following. First, the coefficient of the interaction term between the proportion of $\mathrm{R} \& \mathrm{D}$ operating expenses and $\mathrm{R} \& \mathrm{D}$ input is positive and significant in quantiles 0.1 to 0.3 and decreases as the quantiles increase. Second, the coefficient of the proportion of $R \& D$ operating expenses, and the coefficient of the interaction term between the proportion of $\mathrm{R} \& \mathrm{D}$ operating expenses and human resource training, are both negative and significant in quantiles 0.2 to 0.3 with the negative effect decreases as the quantiles increase. These results not only verify the OLS regression results but also reveal that the moderating effect of the proportion of R\&D operating expenses diminishes with an increase in economic performance and finally becomes insignificant. The possible reason is that $R \& D$ operating expenses has a negative effect on enterprises' economic performance, and enterprises with lower levels of economic performance, usually face greater economic pressure from $\mathrm{R} \& \mathrm{D}$ operating expenses, due to their relatively weaker economic strength. Therefore, these enterprises are more susceptible to the negative effect of R\&D operating expenses when making decisions to actually use the subsidies they obtained, that is, their decisions are moderated by the proportion of $\mathrm{R} \& \mathrm{D}$ operating expenses to a greater extent. Third, the coefficients of the interaction terms between the proportion of R\&D operating expenses and expansion of production capacity are insignificant in all quantiles, which is consistent with the OLS regression results.

The results shown in Panel 3 of Table 3 reveal the following. First, the coefficients of the interaction terms between R\&D input and the proportion of cost for human resource training are not significant in all quantiles with the negative effect decreases and gradually turn to positive as the quantiles increase. Second, the coefficients of the interaction terms between the proportion of cost for human resource training and expansion of production capacity for existing products are negative, significant only at 0.5 quantile with the negative effect decreases as the quantiles increase. Third, the positive coefficients of the interaction terms between human resource training and the proportion of cost for human resource training are not significant in all quantiles with the coefficients decreasing as the quantiles increase. The above results verify the OLS regression results and further reveal that the moderating effect of the proportion of cost for human resource training diminishes as economic performance increases. The possible reason is similar to the previous analysis. It is noted from the results that the proportion of cost for human resource training has a negative effect on economic performance, with the coefficients significant in quantiles 0.3 to 0.6 , and the negative effect diminishes as the quantile increases. Again, since enterprises with better economic performance possess more capital, they can more easily offset the negative effect of the high cost of training human resources. Meanwhile, these enterprises also tend to attract talent with strong technological innovation abilities that can create economic benefits more efficiently. Enterprises in the low quantiles usually have weak economic performances and insufficient investment in human resource training.

\section{Robustness tests}

To ensure the robustness of the empirical results, several robustness tests are performed.

First, the empirical models on which the above conclusions are based only considers a linear relationship between subsidies and economic performance, ignoring the possible non- 
linear relationship between them. To consider a nonlinear relationship, the quadratic term of government subsidies (govsq) is further introduced in Eqs (14) to (16). The coefficient of the quadratic term of subsidies is insignificant in all resulting OLS regressions indicating that no nonlinear relationship exists. Moreover, compared with the above results, the significance and sign of the coefficients are not essentially different, which proves the robustness of our results (see Table A1 of Appendix).

Second, in actual economic activities, whether and how much an enterprise can obtain government subsidies is not random, but affected by its own operating performance and market viability. Government has a high degree of autonomous selectivity in choosing subsidy objects (Boeing, 2016). Therefore, the endogenous issue cannot be ignored. We used two commonly used methods to test the robustness of endogenous problems. The first is the propensity score matching (PSM) method. Based on the difference of the amount of government subsidies received by enterprises, the k-nearest neighbor matching, radius matching, and local linear regression matching were used to match the samples, and PSM model was constructed. Referring to the main stream literatures, we first construct a new variable based on government subsides (lngov), that is, whether the government subsidies received by the enterprise is at a high level (govhigh). Specifically, we compare lngov with its median level, if lngov is higher or equal to the median level, govhigh is valued to 1, otherwise, govhigh is valued to 0 . With govhigh as the explained variable, a logit model was established and the propensity score for obtaining a high level of government subsidies was calculated. After that, we matched samples in three different ways, including nearest neighbor matching with the number of treated and control groups 1:2, matching with 0.001 as the matching radius, and local linear regression matching. To ensure the reliability of the subsequent estimation results, common support test and balance test were carried out first. Based on the observations of the three matching methods respectively, the results of these two tests show that the number of samples lost from matching is relatively limited, so the treated group can find individuals with similar scores in the control group through matching. Moreover, the standard deviation of the variables is significantly reduced after sample matching, indicating that the PSM eliminates the systematic difference of variables, and the matching results can balance the data. After that, we also carried out the treatment effect analysis. The results based on the observations obtained by three matching methods all show that the average treatment effect of government subsidies on economic performance is significant (see Table A2 of Appendix). Finally, the matched observations were used as the samples for regression analysis based on Eqs (14) to (16). The sign, value, and significance of the variable coefficients are basically consistent with the OLS regression results, again proving the robustness (see Table A3 of Appendix).

In addition, we further used the weak endogenous subsample method to deal with the endogenous issues. Specifically, the median of the economic performance of the whole sample is taken, and all the samples above the median level are eliminated, and only the samples below the median level are retained for weak endogenous subsample regression based on Eqs (14) to (16). The sign and significance of the variable coefficients here are not substantially different from the OLS regression results, which again proves the robustness of the results (see Table A4 of Appendix). 


\section{Conclusions and policy implications}

This study investigates enterprises' use patterns of government subsidies, degree to which subsidies are used for sci-tech innovation, mechanism through which economic performance is affected by different subsidy use patterns, and differences in effects among enterprises with heterogeneous economic performance. According to the theoretical model constructed in this study, enterprises aiming profit maximization are affected by various factors, including unit cost of human resource training, unit cost of R\&D, profitability, and capital output elasticity, when deciding how to use subsidies for different activities (i.e., R\&D input, expansion of production capacity for existing products, and human resource training). With an empirical model constructed, OLS regression and panel QR are successively performed. The empirical results reveal the following.

1. Overall, subsidies can significantly improve economic performance. Specifically, enterprises generally use subsidies in three different ways (i.e. R\&D input, expansion of production capacity for existing products, and human resource training), and differences exist in the significance and degree of the promotion effect of these three use patterns on economic performance. Moreover, the effects of all the three use patterns of subsidies on economic performance are more significant and greater among enterprises with poorer economic performance.

2. The proportion of $R \& D$ operating expenses significantly moderates the effects of $\mathrm{R} \& \mathrm{D}$ input and human resource training on economic performance. Additionally, the proportion of cost for human resource training significantly moderates the effect of expanding production capacity for existing products. These moderating effects are stronger among enterprises with poorer economic performance.

Based on the above conclusions, several policy implications are offered.

1. Since economic performance improves the most when enterprises use subsidies for $\mathrm{R} \& \mathrm{D}$ training, policies related to human resources in sci-tech innovation should be further optimized and enacted to help enterprises attract high-caliber talent and increase investment in the development of existing human resources, which can improve innovation achievements and economic performance.

2. The government should formulate policies to motivate enterprises to use subsidies for $\mathrm{R} \& \mathrm{D}$ activities, reduce the expansion of production capacity of existing products and avoid overcapacity of backward products. This can better assist the market mechanism to play its role, and fully allocate the limited resources to the production and operation activities of enterprises which can best improve the R\&D ability.

3. The government must create a favorable innovation environment and promote competition between enterprises, which can reduce R\&D cost and R\&D personnel development and recruitment costs, and stimulate enterprises to increase investments in R\&D activities and training, thus improving subsidy use efficiency.

4. Different supporting policies should be formulated for different types of enterprises. For enterprises with weak economic performance, the government should further increase the amount of subsidies to boost their R\&D abilities and economic strength. For successful enterprises, highly targeted policy incentives will be conducive to cutting- 
edge technologies, enhancing China's strength in fundamental research and boosting its $\mathrm{R} \& \mathrm{D}$ competitiveness. Besides, to achieve the effect of optimal subsidies, different combinations of subsidies with other types of policies should be formulated according to the characteristics of enterprises in different industries, such as the use of gasoline and electricity taxes in the industry of electric vehicle (Xiao et al., 2020).

\section{Limitations and future research}

This study has also some limitations needed to be considered in the future research. First, the behaviors of enterprises are not only influenced by government subsidies, but also influenced by some other source of cash flow, including debt finance, equity finance, etc. Whether and the extent to which enterprises' actual use of these sources of cash flows affect their investment in R\&D activities and other production and operating activities? What are the specific influencing mechanisms? All these questions deserve more in-depth research. Second, economic performance is not the only measure of output. Especially in the context of China's innovation-driven development strategy, it is essential to take the indicators of innovation output as the dependent variable and study the actual impact of subsidies on R\&D activities and innovation performance, which is also one of the directions of our future research.

\section{Acknowledgements}

The authors are grateful to the editors and anonymous reviewers for their insightful comments and suggestions.

\section{Funding}

This work was supported by the National Academy of Innovation Strategy (NAIS), CAST under Grant [number CXY-ZKQN-2019-025].

\section{Author contributions}

$\mathrm{XY}$ and GH conceived the study and were responsible for the design and development of the data analysis. XY was responsible for the collection, analysis, and interpretation of data. XY wrote the first draft of the article.

\section{Disclosure statement}

This study has no competing financial, professional, or personal interests from other parties.

\section{References}

Akcigit, U., Hanley, D., \& Serrano-Velarde, N. (2021). Back to basics: Basic research spillovers, innovation policy and growth. The Review of Economic Studies, 88(1), 1-43.

https://doi.org/10.1093/restud/rdaa061 
Arrow, K. J. (1962). The economic implications of learning by doing. Review of Economic Studies, 29(3), 155-173. https://doi.org/10.2307/2295952

Bauer, T. D., Dehning, B., \& Stratopoulos, T. C. (2012). The financial performance of global information and communication technology companies. Journal of Information Systems, 26(2), 119-152. https://doi.org/10.2308/isys-50215

Baumol, W. (1990). Entrepreneurship: Productive, unproductive, and destructive. Journal of Political Economy, 98(5), 893-921. https://doi.org/10.1086/261712

Becker, B. (2015). Public R\&D policies and private R\&D investment: A survey of the empirical evidence. Journal of Economic Surveys, 29(5), 917-942. https://doi.org/10.1111/joes.12074

Bernini, C., \& Pellegrini, G. (2011). How are growth and productivity in private firms affected by public subsidy? Evidence from a regional policy. Regional Science \& Urban Economics, 41(3), 253-265. https://doi.org/10.1016/j.regsciurbeco.2011.01.005

Boeing, P. (2016). The allocation and effectiveness of China's R\&D subsidies: Evidence from listed firms. Research Policy, 45(9), 1774-1789. https://doi.org/10.1016/j.respol.2016.05.007

Boselie, P., Dietz, G., \& Boon, C. (2005). Commonalities and contradictions in HRM and performance research. Human Resource Management Journal, 15(3), 67-94. https://doi.org/10.1111/j.1748-8583.2005.tb00154.x

Brou, D., \& Ruta, M. (2013). Rent seeking, market structure, and growth. The Scandinavian Journal of Economics, 115, 878-901. https://doi.org/10.1111/sjoe.12014

Carboni, O. A. (2017). The effect of public support on investment and R\&D: An empirical evaluation on European manufacturing firms. Technological Forecasting and Social Change, 117, 282-295. https://doi.org/10.1016/j.techfore.2016.11.017

Chen, C. R., \& Huang, Y. (2011). Mutual fund governance and performance: A quantile regression analysis of Morningstar's stewardship grade. Corporate Governance: An International Review, 19(4), 311-333. https://doi.org/10.1111/j.1467-8683.2011.00858.x

Chen, G., \& Breedlove, J. (2020). The effect of innovation-driven policy on innovation efficiency: Based on the listed sports firms on Chinese new Third Board. International Journal of Sports Marketing and Sponsorship, 21(4), 735-755. https://doi.org/10.1108/IJSMS-12-2019-0136

Chen, Y., Chen, M., \& Mishra, A. K. (2020). Subsidies under uncertainty: Modeling of input- and outputoriented policies. Economic Modelling, 85, 39-56. https://doi.org/10.1016/j.econmod.2019.05.005

Cin, B. C., Kim, Y. J., \& Vonortas, N. S. (2017). The impact of public R\&D subsidy on small firm productivity: Evidence from Korean SMEs. Small Business Economics, 48(2), 345-360. https://doi.org/10.1007/s11187-016-9786-x

Clausen, T. H. (2009). Do subsidies have positive impacts on R\&D and innovation activities at the firm level? Structural Change \& Economic Dynamics, 20(4), 239-253. https://doi.org/10.1016/j.strueco.2009.09.004

Cohen, W. M. (2010). Fifty years of empirical studies of innovative activity and performance. In B. H. Hall, \& N. Rosenberg (Eds.), Handbook of the economics of innovation (pp. 129-213). NorthHolland. https://doi.org/10.1016/S0169-7218(10)01004-X

Colombo, M. G., Grilli, L., \& Murtinu, S. (2011). R\&D subsidies and the performance of high-tech start-ups. Economics Letters, 112(1), 97-99. https://doi.org/10.1016/j.econlet.2011.03.007

Dai, X., \& Cheng, L. (2015). The effect of public subsidies on corporate R\&D investment: An application of the generalized propensity score. Technological Forecasting and Social Change, 90(2), 410-419. https://doi.org/10.1016/j.techfore.2014.04.014

Frankenfield, J. (2020, August 21). Research and development $(R \& D)$ expenses definition. Investopedia. https://www.investopedia.com/terms/r/research-and-development-expenses.asp 
Garcia, A., \& Mohnen, P. (2010). Impact of government support on R\&D and innovation (MERIT Working Papers No. 2010-034). United Nations University, Maastricht Economic and Social Research Institute on Innovation and Technology (MERIT).

Gelabert, L., Fosfuri, A., \& Tribó, J. A. (2009). Does the effect of public support for R\&D depend on the degree of appropriability? Journal of Industrial Economics, 57(4), 736-767. https://doi.org/10.1111/j.1467-6451.2009.00396.x

Geroski, P., \& Machin, S. (2006). Do innovating firms outperform non-innovators? Business Strategy Review, 3(2), 79-90. https://doi.org/10.1111/j.1467-8616.1992.tb00030.x

Gomez, M. A., \& Sequeira, T. N. (2014). Should the U.S. increase subsidies to R\&D? Lessons from an endogenous growth theory. Oxford Economic Papers, 66(1), 254-282. https://doi.org/10.1093/oep/gpt007

Guellec, D., \& van Pottelsberghe de la Potterie, B. (2000). The impact of public R\&D expenditure on business R\&D. Economics of Innovation and New Technology, 12(3), 225-243. https://doi.org/10.1080/10438590290004555

Guo, D., Guo, Y., \& Jiang, K. (2016). Government-subsidized R\&D and firm innovation: Evidence from China. Research Policy, 45(6), 1129-1144. https://doi.org/10.1016/j.respol.2016.03.002

Hassine, H. B., \& Mathieu, C. (2020). R\&D crowding out or R\&D leverage effects: An evaluation of the French cluster-oriented technology policy. Technological Forecasting and Social Change, 155, 120025. https://doi.org/10.1016/j.techfore.2020.120025

Hogendoorn, B., Rud, I., Groot, W., \& van den Brink, H. M. (2019). The effects of human capital interventions on entrepreneurial performance in industrialized countries. Journal of Economic Surveys, 33(3), 798-826. https://doi.org/10.1111/joes.12308

Jin, Z., Shang, Y., \& Xu, J. (2018). The impact of government subsidies on private R\&D and firm performance: Does ownership matter in China's manufacturing industry? Sustainability, 10(7), 2205. https://doi.org/10.3390/su10072205

Jose, M., \& Sharma, R. (2020). Effectiveness of fiscal incentives for innovation: Evidence from meta-regression analysis. Journal of Public Affairs, e2146. https://doi.org/10.1002/pa.2146

Jugend, D., Fiorini, P. D. C., Armellini, F., \& Ferrari, A. G. (2020). Public support for innovation: A systematic review of the literature and implications for open innovation. Technological Forecasting and Social Change, 156, 119985. https://doi.org/10.1016/j.techfore.2020.119985

Kanwar, S., \& Evenson, R. (2003). Does intellectual property protection spur technological change? Oxford Economic Papers, 55(2), 235-264. https://doi.org/10.1093/oep/55.2.235

Kenton, W. (2021, March 20). Operating expense. Investopedia. https://www.investopedia.com/terms/o/ operating_expense.asp

Kim, K. (2021). Output additionality of R\&D subsidy on manufacturing venture firms in Korea: The moderating role of subcontracting regime. European Journal of Innovation Management, 24(2), 290-314. https://doi.org/10.1108/EJIM-05-2019-0130

Kleer, R. (2010). Government R\&D subsidies as a signal for private investors. Research Policy, 39(10), 1361-1374. https://doi.org/10.1016/j.respol.2010.08.001

Klemperer, P. (1990). How broad should the scope of patent protection be? Rand Journal of Economics, 21(1), 113-130. https://doi.org/10.2307/2555498

Lai, Y.-B. (2020). Rent-seeking, R\&D, and productivity. Scottish Journal of Political Economy, 67(4), 404-419. https://doi.org/10.1111/sjpe.12243

Li, J., Ren, H., Zhang, C., Li, Q., \& Duan, K. (2020). Substantive innovation or strategic innovation? Research on multiplayer stochastic evolutionary game model and simulation. Complexity, 2020, 1-15. https://doi.org/10.1155/2020/8882813 
Lin, S.-H., Li, J.-H., Hsu, C.-C., Hsieh, J.-C., \& Liao, P.-C. (2018). The strategic exercise of options using government subsidies: An analysis of production subsidies for the ground source heat pump. Journal of Physics: Conference Series, 989(1), 012003. https://doi.org/10.1088/1742-6596/989/1/012003

London, S., Brida, J. G., \& Risso, W. A. (2008). Human capital and innovation: A model of endogenous growth with a "skill-loss effect". Economics Bulletin, 15(7), 1-10. http://www.accessecon.com/pubs/ EB/2008/Volume15/EB-08O10001A.pdf

Mckenzie, J., \& Walls, W. D. (2013). Australian films at the Australian box office: Performance, distribution, and subsidies. Journal of Cultural Economics, 37(2), 247-269. https://doi.org/10.1007/s10824-012-9181-7

Murphy, K. M., Shleifer, A., \& Vishny, R. W. (1991). The allocation of talent: Implications for growth. The Quarterly Journal of Economics, 106(2), 503-530. https://doi.org/10.2307/2937945

Nie, P., Xiao, X., Wang, C., \& Cui, T. (2020). Innovation subsidy under duopoly. Managerial and Decision Economics, 41(3), 362-370. https://doi.org/10.1002/mde.3105

Perera, A. (2012). Impact of measuring and reporting human resource on investment decisions in Sri Lanka. International Proceedings of Economics Development and Research, 54(8), 38-42. https://doi.org/10.2139/ssrn.2115274

Powell, D., \& Wagner, J. (2014). The exporter productivity premium along the productivity distribution: Evidence from quantile regression with nonadditive firm fixed effects. Review of World Economics, 150(4), 763-785. https://doi.org/10.1007/s10290-014-0192-7

Redding, S. (1996). The low-skill, low-quality trap: Strategic complementarities between human capital and R\&D. Economic Journal, 106(435), 458-470. https://doi.org/10.2307/2235260

Russo, C., Goodhue, R. E., \& Sexton, R. J. (2011). Agricultural support policies in imperfectly competitive markets: Why market power matters in policy design. American Journal of Agricultural Economics, 93(5), 1328-1340. https://doi.org/10.1093/ajae/aar050

Shen, X., \& Lin, B. (2020). Policy incentives, R\&D investment, and the energy intensity of China's manufacturing sector. Journal of Cleaner Production, 255, 120208. https://doi.org/10.1016/j.jclepro.2020.120208

Sissoko, A. (2011). R\&D subsidies and firm-level productivity: Evidence from France (Discussion Papers). Institut de Recherches Economiques et Sociales (IRES).

Sun, Y., \& Cao, C. (2016). China: Standardize R\&D costing. Nature, 536, 30. https://doi.org/10.1038/536030b

Szucs, F. (2020). Do research subsidies crowd out private R\&D of large firms? Evidence from European Framework Programmes. Research Policy, 49(3), 103923. https://doi.org/10.1016/j.respol.2020.103923

Tao, Q., Sun, Y., Zhu, Y., \& Yang, X. (2017). Political connections and government subsidies: Evidence from financially distressed firms in China. Emerging Markets Finance and Trade, 53(8), 1854-1868. https://doi.org/10.1080/1540496X.2017.1332592

Tebourbi, I., Ting, I. W. K., Le, H. T. M., \& Kweh, Q. L. (2020). R\&D investment and future firm performance: The role of managerial overconfidence and government ownership. Managerial and Decision Economics, 41(1), 1269-1281. https://doi.org/10.1002/mde.3173

Tzelepis, D., \& Skuras, D. (2004). The effects of regional capital subsidies on firm performance: An empirical study. Journal of Small Business and Enterprise Development, 11(1), 121-129. https://doi.org/10.1108/14626000410519155

Tzelepis, D., \& Skuras, D. (2006). Strategic performance measurement and the use of capital subsidies. International Journal of Productivity and Performance Management, 55(7), 527-538. https://doi.org/10.1108/17410400610702133 
Xiao, D. D., Zhu, G. L., \& Wang, J. (2013). The impact of government S\&T input on the enterprise's $\mathrm{R} \& \mathrm{D}$ expenditure-empirical research based on a quantile regression. $R \& D$ Management, $25,25-32$. https://doi.org/10.1016/j.energy.2020.118375

Xiao, X., Chen, Z.-R., \& Nie, P.-Y. (2020). Analysis of two subsidies for EVs: Based on an expanded theoretical discrete-choice model. Energy, 208, 118375.

Yu, F., Guo, Y., Le-Nguyen, K., Barnes, S. J., \& Zhang, W. (2016). The impact of government subsidies and enterprises' R\&D investment: A panel data study from renewable energy in China. Energy Policy, 89, 106-113. https://doi.org/10.1016/j.enpol.2015.11.009

Zhao, S., Xu, B., \& Zhang, W. (2018). Government R\&D subsidy policy in China: An empirical examination of effect, priority, and specifics. Technological Forecasting and Social Change, 135, 75-82. https://doi.org/10.1016/j.techfore.2017.10.004 


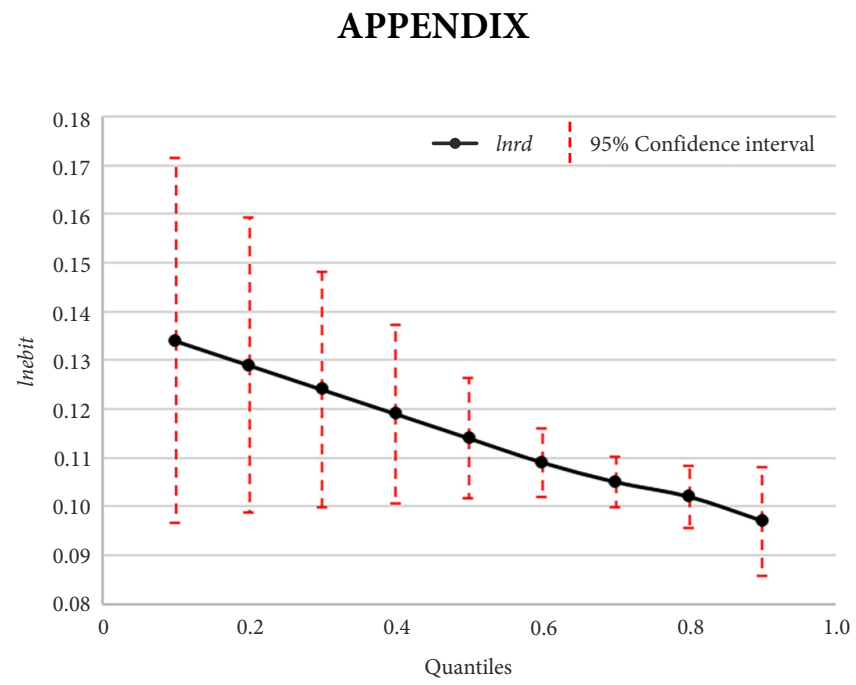

Figure A1. Effect of R\&D input on economic performance

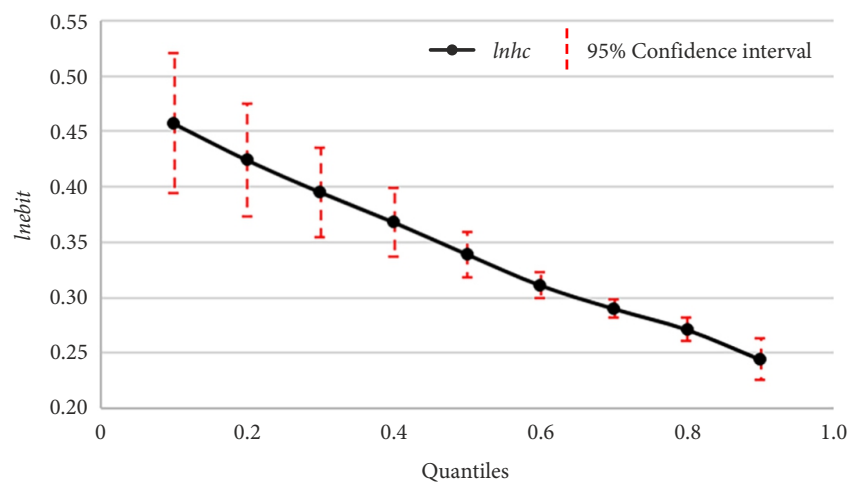

Figure A2. Effect of human resource training on economic performance

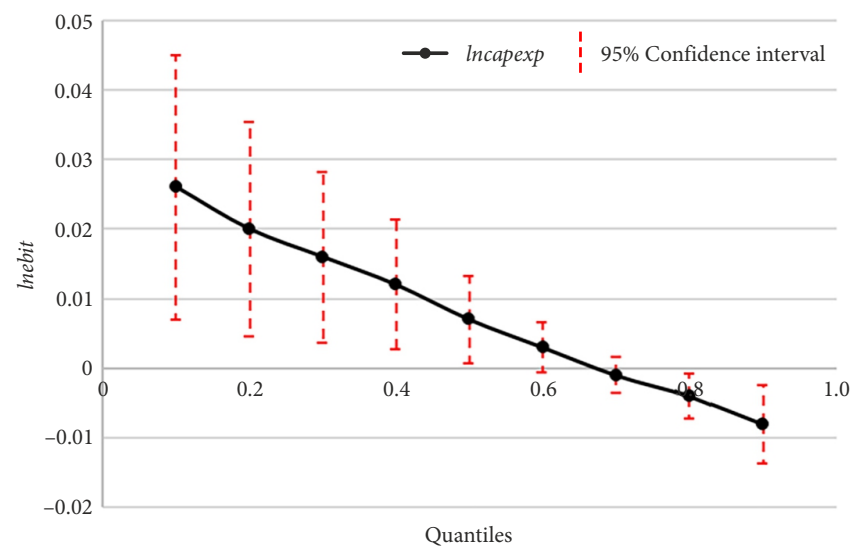

Figure A3. Effect of expanding production capacity for existing products on economic performance 
a) Effect of $r d c$ on lnebit

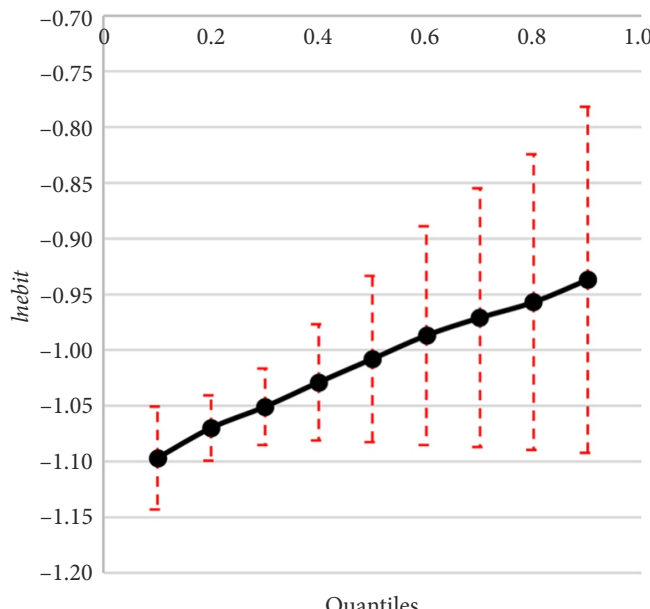

Quantiles

c) Effect of $r d c^{\star} \operatorname{lncapexp}$ on lnebit

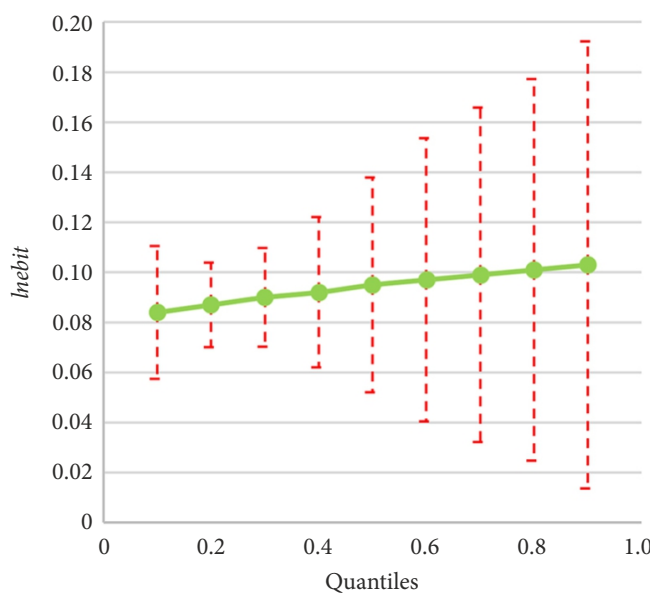

$-r d c-r d c^{*} \ln r d-r d c^{*} \operatorname{lncapexp}$ b) Effect of $r d c^{\star} \ln r d$ on lnebit

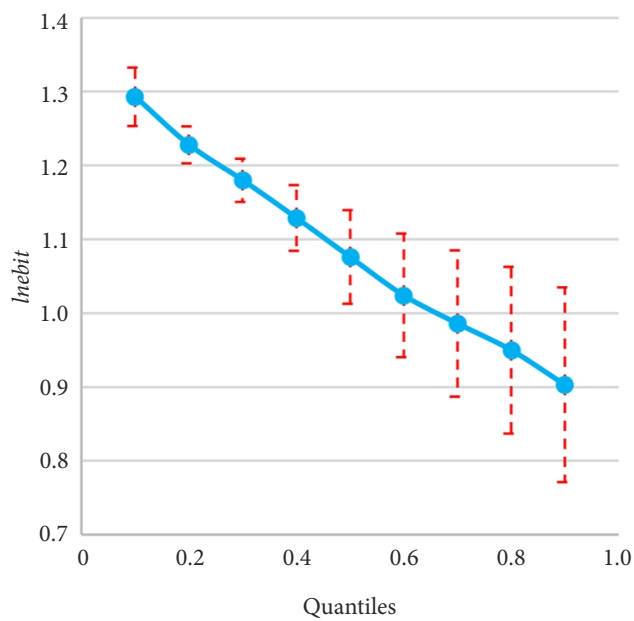

d) Effect of $r d c^{\star} \operatorname{lnh} c$ on lnebit

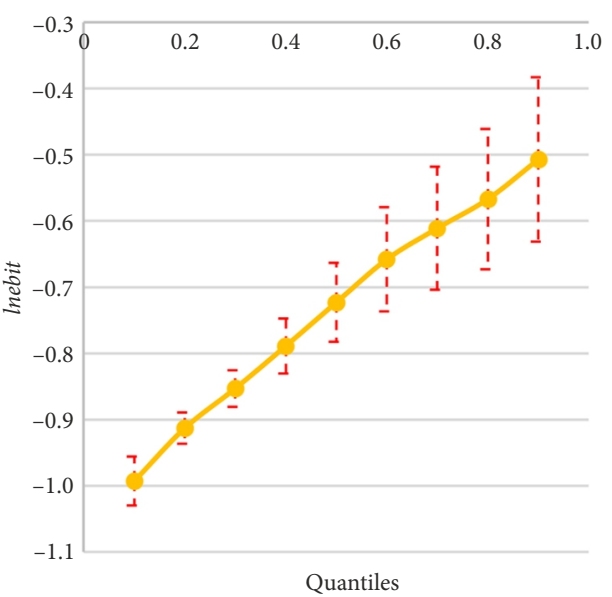

$r d c^{*} l n h c \quad 95 \%$ Confidence interval

Figure A4. Moderating effect of proportion of R\&D operating expenses on the relationship between three uses of government subsidies and economic performance 
a) Effect of $l c$ on lnebit

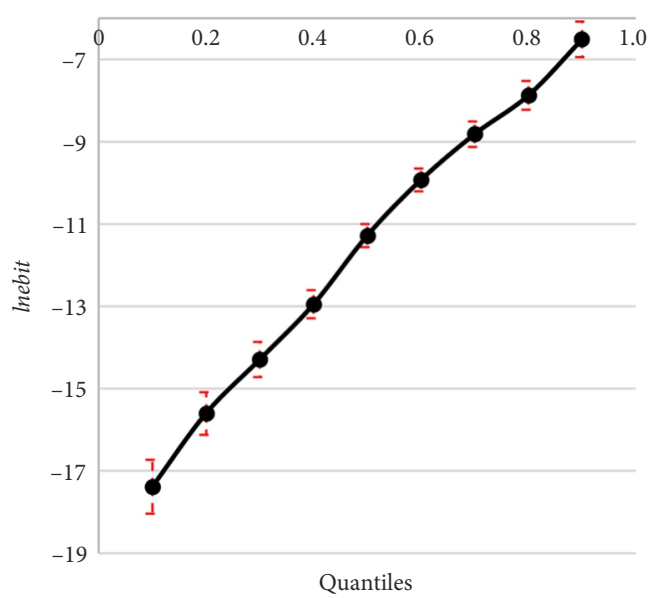

c) Effect of $l c^{\star} \operatorname{lncapexp}$ on lnebit

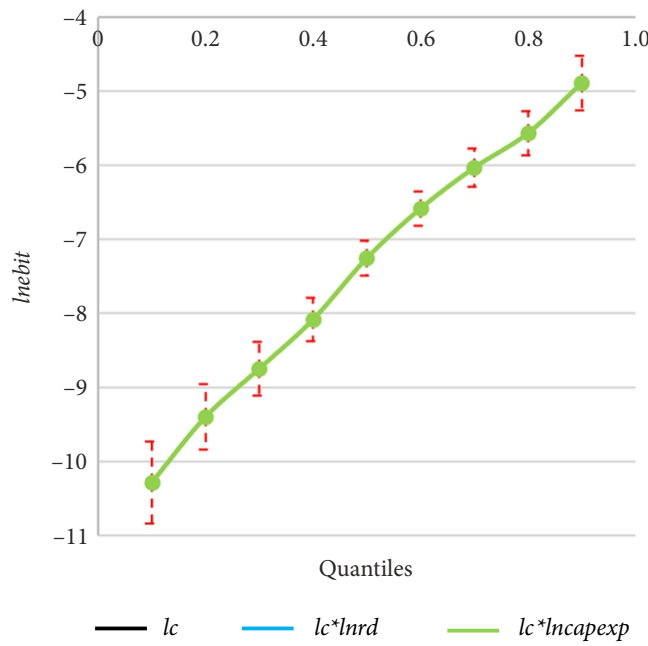

b) Effect of $l c^{\star} \ln r d$ on lnebit

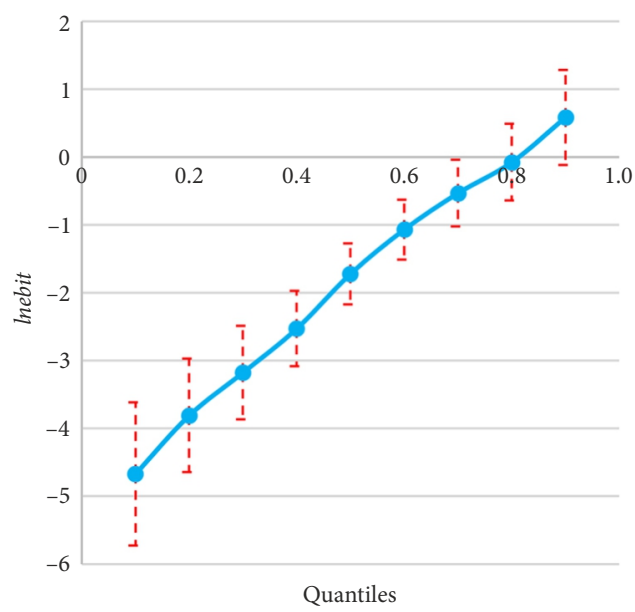

d) Effect of $l c^{\star} \operatorname{lnh} c$ on lnebit

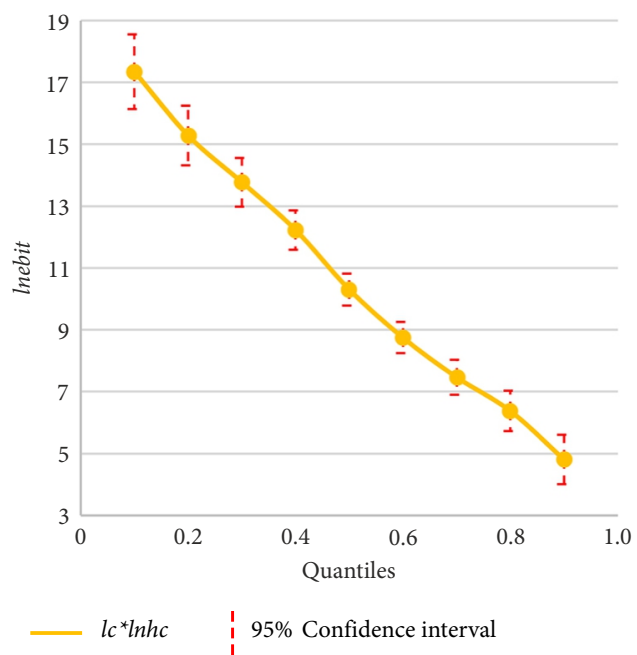

Figure A5. Moderating effect of proportion of human resource training cost on the relationship between three uses of government subsidies and economic performance 
Table A1. Robustness test for non-linear relationship of government subsidies

\begin{tabular}{|c|c|c|c|}
\hline & (14) & (15) & (16) \\
\hline & lnebit & lnebit & lnebit \\
\hline $\ln r d$ & $\begin{array}{c}0.013 \\
(0.026)\end{array}$ & $\begin{array}{c}0.196^{\star * \star} \\
(0.048)\end{array}$ & $\begin{array}{c}-0.004 \\
(0.148)\end{array}$ \\
\hline lncapexp & $\begin{array}{c}0.058^{\star * *} \\
(0.018)\end{array}$ & $\begin{array}{l}0.039^{\star *} \\
(0.018)\end{array}$ & $\begin{array}{l}-0.069 \\
(0.067)\end{array}$ \\
\hline $\operatorname{lnh} c$ & $\begin{array}{c}0.216^{\star * *} \\
(0.041)\end{array}$ & $\begin{array}{c}0.144^{* * *} \\
(0.044)\end{array}$ & $\begin{array}{l}0.48^{\star * *} \\
(0.166)\end{array}$ \\
\hline lngov & $\begin{array}{c}0.044^{* * *} \\
(0.015)\end{array}$ & $\begin{array}{c}0.041^{\star * \star} \\
(0.015)\end{array}$ & $\begin{array}{c}0.042^{* * *} \\
(0.014)\end{array}$ \\
\hline govsq & $\begin{array}{c}0.006 \\
(0.009)\end{array}$ & $\begin{array}{c}0.001 \\
(0.009)\end{array}$ & $\begin{array}{c}0.005 \\
(0.009)\end{array}$ \\
\hline$r d c$ & $\begin{array}{c}0.084 \\
(0.109)\end{array}$ & $\begin{array}{c}-0.695^{\star * *} \\
(0.195)\end{array}$ & $\begin{array}{c}0.141 \\
(0.138)\end{array}$ \\
\hline$l c$ & $\begin{array}{l}-1.514 \\
(1.922)\end{array}$ & $\begin{array}{l}-2.795 \\
(2.787)\end{array}$ & $\begin{array}{c}-10.67^{* * *} \\
(3.827)\end{array}$ \\
\hline profitp & $\begin{array}{c}165.372^{* * *} \\
(14.589)\end{array}$ & $\begin{array}{c}177.964^{* * *} \\
(15.321)\end{array}$ & $\begin{array}{c}172.026^{* * *} \\
(16.04)\end{array}$ \\
\hline lneps & $\begin{array}{c}0.316^{* * *} \\
(0.04)\end{array}$ & $\begin{array}{c}0.283^{\star * *} \\
(0.038)\end{array}$ & $\begin{array}{c}0.326^{\star \star \star} \\
(0.039)\end{array}$ \\
\hline lnasset & $\begin{array}{l}0.67^{\star * *} \\
(0.048)\end{array}$ & $\begin{array}{c}0.606^{* * *} \\
(0.049)\end{array}$ & $\begin{array}{c}0.636^{* * *} \\
(0.047)\end{array}$ \\
\hline growth & $\begin{array}{c}0.045 \\
(0.105)\end{array}$ & $\begin{array}{c}0.184 \\
(0.123)\end{array}$ & $\begin{array}{l}-0.029 \\
(0.112)\end{array}$ \\
\hline lev & $\begin{array}{c}-6.123^{* * *} \\
(0.845)\end{array}$ & $\begin{array}{c}-6.53^{\star * *} \\
(0.899)\end{array}$ & $\begin{array}{c}-6.228^{\star * *} \\
(0.836)\end{array}$ \\
\hline cash & $\begin{array}{c}-0.042^{\star *} \\
(0.021)\end{array}$ & $\begin{array}{l}-0.021 \\
(0.016)\end{array}$ & $\begin{array}{c}-0.038^{\star} \\
(0.02)\end{array}$ \\
\hline turnover & $\begin{array}{c}0.103^{\star * *} \\
(0.04)\end{array}$ & $\begin{array}{l}0.085^{\star \star} \\
(0.033)\end{array}$ & $\begin{array}{l}0.092^{\star *} \\
(0.036)\end{array}$ \\
\hline concen & $\begin{array}{l}-0.014 \\
(0.015)\end{array}$ & $\begin{array}{l}-0.012 \\
(0.015)\end{array}$ & $\begin{array}{l}-0.017 \\
(0.015)\end{array}$ \\
\hline lnmshare & $\begin{array}{c}0.017 \\
(0.012)\end{array}$ & $\begin{array}{c}0.014 \\
(0.011)\end{array}$ & $\begin{array}{c}0.011 \\
(0.012)\end{array}$ \\
\hline $\ln r d^{*} r d c$ & & $\begin{array}{c}0.969^{* * *} \\
(0.215)\end{array}$ & \\
\hline $\operatorname{lncapexp}{ }^{*} r d c$ & & $\begin{array}{c}-0.092 \\
(0.12)\end{array}$ & \\
\hline $\operatorname{lnh} c^{\star} r d c$ & & $\begin{array}{c}-0.399^{* *} \\
(0.176)\end{array}$ & \\
\hline $\ln r d^{*} l c$ & & & $\begin{array}{l}-0.429 \\
(6.079)\end{array}$ \\
\hline $\operatorname{lncapexp}{ }^{*} l c$ & & & $\begin{array}{l}-5.41^{\star} \\
(3.061)\end{array}$ \\
\hline $\operatorname{lnh} c^{*} l c$ & & & $\begin{array}{l}10.051 \\
(6.832)\end{array}$ \\
\hline industry & yes & yes & yes \\
\hline province & yes & yes & yes \\
\hline year & yes & yes & yes \\
\hline Constant & $\begin{array}{c}-2.047^{* * *} \\
(0.174)\end{array}$ & $\begin{array}{c}-2.302^{* * *} \\
(0.2)\end{array}$ & $\begin{array}{c}-2.32^{\star * *} \\
(0.225)\end{array}$ \\
\hline No. of Obs. & 1317 & 1317 & 1317 \\
\hline$R$-squared & 0.900 & 0.908 & 0.903 \\
\hline
\end{tabular}

Notes: Clustered robust standard errors are in parentheses. ${ }^{\star * \star},{ }^{\star *}$ and ${ }^{\star}$ denote statistical significance at $1 \%, 5 \%$ and $10 \%$ levels, respectively. Inebit, economic performance; $\ln r d$, R\&D input; lncapexp, expansion of production capacity for existing products; $l n h c$, human resource training; lngov, government subsidies; govsq, quadratic term of government subsidies; $r d c$, proportion of R\&D operating expenses; $l c$, proportion of human resource training cost; profitp, profitability; Ineps, capital profitability; Inasset, size; growth, growth ability; lev, financial risk; cash, short-term solvency; turnover, operating ability; concen, equity concentration; lnmshare, management shareholding. 
Table A2. Average treatment effect of government subsidies on economic performance

\begin{tabular}{|c|c|c|c|c|c|}
\hline & Treated Group & Control Group & ATT & S.E. & T-stat \\
\hline K-nearest matching (1:2) & 0.247 & 0.191 & 0.056 & 0.018 & 3.13 \\
\hline Radius matching & 0.212 & 0.154 & 0.059 & 0.014 & 4.11 \\
\hline Local linear regression matching & 0.247 & 0.189 & 0.057 & 0.02 & 2.88 \\
\hline
\end{tabular}

Notes: ATT, the average treatment effect on the treated, represents the average treatment effect calculated based on the matched samples. If the $t$-statistic of ATT is higher than the critical value of 1.96, then the average treatment effect of government subsidies on economic performance is significant.

Table A3. Robustness test for endogeneity problem (Propensity score matching method)

\begin{tabular}{|c|c|c|c|c|c|c|c|c|c|}
\hline & \multicolumn{3}{|c|}{$\begin{array}{c}\text { K-nearest neighbor } \\
\text { matching }(1: 2)\end{array}$} & \multicolumn{3}{|c|}{$\begin{array}{c}\text { Radius } \\
\text { matching }\end{array}$} & \multicolumn{3}{|c|}{$\begin{array}{c}\text { Local linear regression } \\
\text { matching }\end{array}$} \\
\hline & (14) & (15) & (16) & (14) & (15) & (16) & (14) & (15) & (16) \\
\hline & lnebit & lnebit & lnebit & lnebit & lnebit & lnebit & lnebit & lnebit & lnebit \\
\hline $\ln r d$ & $\begin{array}{c}0.02 \\
(0.026)\end{array}$ & $\begin{array}{l}0.204^{\star * *} \\
(0.046)\end{array}$ & $\begin{array}{c}0.016 \\
(0.138)\end{array}$ & $\begin{array}{c}0.024 \\
(0.026)\end{array}$ & $\begin{array}{c}0.207^{* * *} \\
(0.046)\end{array}$ & $\begin{array}{c}0.01 \\
(0.138)\end{array}$ & $\begin{array}{c}0.021 \\
(0.026)\end{array}$ & $\begin{array}{c}0.204^{* * *} \\
(0.046)\end{array}$ & $\begin{array}{c}0.01 \\
(0.139)\end{array}$ \\
\hline Incapexp & $\begin{array}{c}0.059^{* * *} \\
(0.018)\end{array}$ & $\begin{array}{l}0.041^{* *} \\
(0.018)\end{array}$ & $\begin{array}{l}-0.071 \\
(0.064)\end{array}$ & $\begin{array}{c}0.061^{* * *} \\
(0.018)\end{array}$ & $\begin{array}{l}0.042^{\star *} \\
(0.018)\end{array}$ & $\begin{array}{l}-0.075 \\
(0.064)\end{array}$ & $\begin{array}{c}0.059^{* * *} \\
(0.018)\end{array}$ & $\begin{array}{l}0.041^{* *} \\
(0.018)\end{array}$ & $\begin{array}{l}-0.073 \\
(0.064)\end{array}$ \\
\hline $\operatorname{lnh} c$ & $\begin{array}{c}0.211^{\star * *} \\
(0.041)\end{array}$ & \begin{tabular}{|c|}
$0.135^{* * *}$ \\
$(0.044)$ \\
\end{tabular} & $\begin{array}{l}0.451^{* * *} \\
(0.157)\end{array}$ & $\begin{array}{c}0.207^{* * *} \\
(0.04)\end{array}$ & $\begin{array}{c}0.132^{* * *} \\
(0.043)\end{array}$ & $\begin{array}{l}0.467^{* * *} \\
(0.157)\end{array}$ & $\begin{array}{c}0.213^{* * *} \\
(0.041)\end{array}$ & $\begin{array}{c}0.137^{* * *} \\
(0.044)\end{array}$ & $\begin{array}{c}0.463^{* * *} \\
(0.158)\end{array}$ \\
\hline$r d c$ & $\begin{array}{c}0.072 \\
(0.112)\end{array}$ & \begin{tabular}{|c|}
$-0.726^{* * *}$ \\
$(0.192)$
\end{tabular} & $\begin{array}{c}0.119 \\
(0.137)\end{array}$ & $\begin{array}{c}0.08 \\
(0.112)\end{array}$ & $\begin{array}{c}-0.716^{* * *} \\
(0.191)\end{array}$ & $\begin{array}{c}0.131 \\
(0.137)\end{array}$ & $\begin{array}{c}0.073 \\
(0.111)\end{array}$ & \begin{tabular}{|c|}
$-0.721^{* * \star}$ \\
$(0.192)$
\end{tabular} & $\begin{array}{c}0.124 \\
(0.136)\end{array}$ \\
\hline lc & \begin{tabular}{|l|}
-1.301 \\
$(1.961)$ \\
\end{tabular} & $\begin{array}{c}-2.31 \\
(2.731)\end{array}$ & $\begin{array}{c}-10.113^{* * *} \\
(3.768)\end{array}$ & $\begin{array}{l}-1.45 \\
(1.96)\end{array}$ & $\begin{array}{l}-2.605 \\
(2.691)\end{array}$ & $\begin{array}{c}-10.503^{* * *} \\
(3.745)\end{array}$ & $\begin{array}{l}-1.315 \\
(1.944) \\
\end{array}$ & $\begin{array}{l}-2.368 \\
(2.705) \\
\end{array}$ & $\begin{array}{c}-10.177^{* * *} \\
(3.764)\end{array}$ \\
\hline profitp & $\begin{array}{c}168.206^{* * *} \\
(14.44)\end{array}$ & $\begin{array}{c}180.432^{\star * *} \\
(15.11)\end{array}$ & $\begin{array}{c}174.334^{* * *} \\
(15.818)\end{array}$ & $\begin{array}{c}170.268^{* * *} \\
(14.677) \\
\end{array}$ & $\begin{array}{c}182.372^{* * *} \\
(15.301)\end{array}$ & $\begin{array}{c}176.228^{* * *} \\
(15.893)\end{array}$ & \begin{tabular}{|c|}
$168.789^{* * *}$ \\
$(14.533)$ \\
\end{tabular} & $\begin{array}{c}180.876^{* * *} \\
(15.167) \\
\end{array}$ & $\begin{array}{c}174.984^{* * *} \\
(15.833)\end{array}$ \\
\hline lneps & $\begin{array}{c}0.297^{\star * *} \\
(0.037)\end{array}$ & $\begin{array}{c}0.265^{* * *} \\
(0.035)\end{array}$ & $\begin{array}{c}0.306^{* * *} \\
(0.036)\end{array}$ & $\begin{array}{l}0.3^{* * *} \\
(0.038)\end{array}$ & $\begin{array}{c}0.268^{* * *} \\
(0.036)\end{array}$ & $\begin{array}{l}0.31^{* * *} \\
(0.037)\end{array}$ & $\begin{array}{l}0.3^{* * *} \\
(0.037)\end{array}$ & $\begin{array}{c}0.267^{\star * *} \\
(0.036)\end{array}$ & $\begin{array}{c}0.309^{* * *} \\
(0.037)\end{array}$ \\
\hline lnasset & $\begin{array}{c}0.685^{* * *} \\
(0.047)\end{array}$ & $\begin{array}{c}0.618^{* * *} \\
(0.048)\end{array}$ & $\begin{array}{c}0.653^{* * *} \\
(0.046)\end{array}$ & $\begin{array}{c}0.687^{* * *} \\
(0.047)\end{array}$ & $\begin{array}{c}0.619^{* * *} \\
(0.048)\end{array}$ & $\begin{array}{c}0.652^{\star * *} \\
(0.046)\end{array}$ & $\begin{array}{c}0.684^{* * *} \\
(0.047)\end{array}$ & $\begin{array}{c}0.617^{* * *} \\
(0.048)\end{array}$ & $\begin{array}{c}0.651^{* * *} \\
(0.047)\end{array}$ \\
\hline growth & $\begin{array}{c}0.09 \\
(0.103)\end{array}$ & $\begin{array}{l}0.224^{*} \\
(0.126)\end{array}$ & $\begin{array}{c}0.023 \\
(0.109)\end{array}$ & $\begin{array}{c}0.117 \\
(0.105)\end{array}$ & $\begin{array}{c}0.249^{*} \\
(0.128)\end{array}$ & $\begin{array}{c}0.039 \\
(0.109)\end{array}$ & $\begin{array}{c}0.095 \\
(0.104)\end{array}$ & $\begin{array}{c}0.228^{*} \\
(0.127)\end{array}$ & $\begin{array}{c}0.025 \\
(0.109)\end{array}$ \\
\hline lev & $\begin{array}{c}-6.186^{\star * \star} \\
(0.856) \\
\end{array}$ & $\begin{array}{c}-6.611^{\star * \star} \\
(0.893)\end{array}$ & $\begin{array}{c}-6.29^{* \star *} \\
(0.85)\end{array}$ & $\begin{array}{c}-6.241^{\star * *} \\
(0.852)\end{array}$ & $\begin{array}{c}-6.651^{* * *} \\
(0.887)\end{array}$ & $\begin{array}{c}-6.344^{* \star *} \\
(0.844)\end{array}$ & $\begin{array}{c}-6.203^{* * *} \\
(0.851)\end{array}$ & $\begin{array}{c}-6.619^{* * *} \\
(0.887)\end{array}$ & $\begin{array}{c}-6.312^{\star * *} \\
(0.844)\end{array}$ \\
\hline cash & $\begin{array}{c}-0.042^{* *} \\
(0.02)\end{array}$ & $\begin{array}{l}-0.022 \\
(0.015)\end{array}$ & $\begin{array}{c}-0.038^{\star *} \\
(0.019)\end{array}$ & $\begin{array}{c}-0.041^{\star *} \\
(0.02)\end{array}$ & $\begin{array}{l}-0.021 \\
(0.015)\end{array}$ & $\begin{array}{c}-0.037^{\star} \\
(0.019)\end{array}$ & $\begin{array}{c}-0.042^{\star \star} \\
(0.02)\end{array}$ & \begin{tabular}{|l|}
-0.022 \\
$(0.015)$
\end{tabular} & $\begin{array}{c}-0.038^{\star *} \\
(0.019)\end{array}$ \\
\hline turnover & $\begin{array}{c}0.106^{* * *} \\
(0.039)\end{array}$ & $\begin{array}{c}0.088^{* * *} \\
(0.032)\end{array}$ & $\begin{array}{c}0.096^{* * *} \\
(0.035)\end{array}$ & $\begin{array}{c}0.103^{* * *} \\
(0.039)\end{array}$ & $\begin{array}{c}0.085^{* * *} \\
(0.032)\end{array}$ & $\begin{array}{c}0.093^{* * *} \\
(0.036)\end{array}$ & $\begin{array}{c}0.106^{* * *} \\
(0.039)\end{array}$ & $\begin{array}{c}0.088^{\star * *} \\
(0.032)\end{array}$ & $\begin{array}{c}0.095^{* * *} \\
(0.036)\end{array}$ \\
\hline concen & $\begin{array}{l}-0.013 \\
(0.015)\end{array}$ & $\begin{array}{l}-0.009 \\
(0.014)\end{array}$ & $\begin{array}{l}-0.015 \\
(0.015)\end{array}$ & $\begin{array}{l}-0.013 \\
(0.015)\end{array}$ & $\begin{array}{l}-0.01 \\
(0.014)\end{array}$ & $\begin{array}{l}-0.015 \\
(0.015)\end{array}$ & $\begin{array}{l}-0.013 \\
(0.015)\end{array}$ & $\begin{array}{l}-0.009 \\
(0.014)\end{array}$ & $\begin{array}{l}-0.015 \\
(0.014)\end{array}$ \\
\hline Inmshare & $\begin{array}{c}0.02^{*} \\
(0.011)\end{array}$ & $\begin{array}{l}0.018^{\star} \\
(0.011)\end{array}$ & $\begin{array}{c}0.015 \\
(0.011)\end{array}$ & $\begin{array}{c}0.02^{*} \\
(0.011)\end{array}$ & $\begin{array}{l}0.018^{*} \\
(0.011)\end{array}$ & $\begin{array}{c}0.015 \\
(0.011)\end{array}$ & $\begin{array}{l}0.019^{*} \\
(0.011)\end{array}$ & $\begin{array}{l}0.018^{*} \\
(0.011)\end{array}$ & $\begin{array}{c}0.015 \\
(0.011)\end{array}$ \\
\hline govhigh & $\begin{array}{l}0.06^{* * *} \\
(0.019)\end{array}$ & $\begin{array}{c}0.062^{* * *} \\
(0.018)\end{array}$ & $\begin{array}{c}0.061^{* * *} \\
(0.018)\end{array}$ & $\begin{array}{c}0.062^{* * *} \\
(0.019)\end{array}$ & $\begin{array}{c}0.064^{* * *} \\
(0.018)\end{array}$ & $\begin{array}{c}0.063^{* * *} \\
(0.018)\end{array}$ & $\begin{array}{l}0.06^{\star * *} \\
(0.019)\end{array}$ & $\begin{array}{c}0.062^{\star * *} \\
(0.018)\end{array}$ & $\begin{array}{c}0.061^{* * *} \\
(0.018)\end{array}$ \\
\hline $\ln r d^{*} r d c$ & & $\begin{array}{c}0.993^{* * *} \\
(0.212)\end{array}$ & & & $\begin{array}{l}0.99^{* * *} \\
(0.214)\end{array}$ & & & $\begin{array}{c}0.987^{* * *} \\
(0.213)\end{array}$ & \\
\hline $\operatorname{lncapexp}{ }^{*} r d c$ & & $\begin{array}{l}-0.085 \\
(0.117)\end{array}$ & & & $\begin{array}{l}-0.093 \\
(0.116)\end{array}$ & & & $\begin{array}{l}-0.085 \\
(0.118)\end{array}$ & \\
\hline $\operatorname{lnh} c^{\star} r d c$ & & $\begin{array}{c}-0.429^{* *} \\
(0.171)\end{array}$ & & & $\begin{array}{c}-0.418^{* *} \\
(0.173)\end{array}$ & & & $\begin{array}{l}-.423^{\star *} \\
(0.172)\end{array}$ & \\
\hline
\end{tabular}


End of Table A3

\begin{tabular}{|c|c|c|c|c|c|c|c|c|c|}
\hline & \multicolumn{3}{|c|}{$\begin{array}{l}\text { K-nearest neighbor } \\
\text { matching }(1: 2)\end{array}$} & \multicolumn{3}{|c|}{$\begin{array}{c}\text { Radius } \\
\text { matching }\end{array}$} & \multicolumn{3}{|c|}{$\begin{array}{c}\text { Local linear regression } \\
\text { matching }\end{array}$} \\
\hline & (14) & (15) & (16) & (14) & (15) & (16) & (14) & (15) & (16) \\
\hline & lnebit & lnebit & lnebit & lnebit & lnebit & lnebit & lnebit & lnebit & lnebit \\
\hline $\ln r d^{*} l c$ & & & $\begin{array}{c}0.168 \\
(5.725) \\
\end{array}$ & & & $\begin{array}{l}-0.21 \\
(5.74) \\
\end{array}$ & & & $\begin{array}{l}-0.135 \\
(5.756) \\
\end{array}$ \\
\hline lncapexp ${ }^{*} l c$ & & & $\begin{array}{l}-5.629^{*} \\
(2.933)\end{array}$ & & & $\begin{array}{c}-5.842^{\star *} \\
(2.931)\end{array}$ & & & $\begin{array}{l}-5.699^{*} \\
(2.947)\end{array}$ \\
\hline $\operatorname{lnh} c^{*} l c$ & & & $\begin{array}{c}9.135 \\
(6.501)\end{array}$ & & & $\begin{array}{l}9.856 \\
(6.51)\end{array}$ & & & $\begin{array}{c}9.533 \\
(6.547)\end{array}$ \\
\hline industry & yes & yes & yes & yes & yes & yes & yes & yes & yes \\
\hline province & yes & yes & yes & yes & yes & yes & yes & yes & yes \\
\hline year & yes & yes & yes & yes & yes & yes & yes & yes & yes \\
\hline Constant & $\begin{array}{c}-2.101^{\star * *} \\
(0.172)\end{array}$ & \begin{tabular}{|c|}
$-2.353^{\star * *}$ \\
$(0.197)$
\end{tabular} & \begin{tabular}{|c|}
$-2.362^{\star * *}$ \\
$(0.22)$
\end{tabular} & $\begin{array}{l}-2.12^{* * *} \\
(0.174)\end{array}$ & $\begin{array}{c}-2.374^{* * *} \\
(0.198)\end{array}$ & \begin{tabular}{|c|}
$-2.387^{\star * *}$ \\
$(0.22)$
\end{tabular} & \begin{tabular}{|c|}
$-2.109^{\star * \star}$ \\
$(0.173)$
\end{tabular} & $\begin{array}{l}-2.36^{\star * *} \\
(0.197)\end{array}$ & $\begin{array}{l}-2.372^{\star * *} \\
(0.22)\end{array}$ \\
\hline No. of Obs. & 1359 & 1359 & 1359 & 1359 & 1359 & 1359 & 1359 & 1359 & 1359 \\
\hline$R$-squared & 0.903 & 0.911 & 0.906 & 0.902 & 0.91 & 0.906 & 0.903 & 0.911 & 0.906 \\
\hline
\end{tabular}

Notes: Clustered robust standard errors are in parentheses. ${ }^{* *},{ }^{* *}$ and ${ }^{*}$ denote statistical significance at $1 \%, 5 \%$ and $10 \%$ levels, respectively. lnebit, economic performance; lnrd, R\&D input; lncapexp, expansion of production capacity for existing products; $\ln h c$, human resource training; $r d c$, proportion of R\&D operating expenses; $l c$, proportion of human resource training cost; profitp, profitability; lneps, capital profitability; Inasset, size; growth, growth ability; lev, financial risk; cash, short-term solvency; turnover, operating ability; concen, equity concentration; lnmshare, management shareholding; govhigh, whether the government subsidies received by the enterprise is at a high level (compare lngov with its median level, if lngov is higher or equal to the median level, assign the govhigh value to 1, otherwise, assign it to 0 ).

Table A4. Robustness test for endogeneity problem (Weak endogenous subsample)

\begin{tabular}{|c|c|c|c|}
\hline & (14) & (15) & (16) \\
\hline & lnebit & lnebit & lnebit \\
\hline $\ln r d$ & $\begin{array}{c}0.02 \\
(0.044) \\
\end{array}$ & $\begin{array}{c}0.227^{* * *} \\
(0.066)\end{array}$ & $\begin{array}{l}0.327 \\
(0.22) \\
\end{array}$ \\
\hline lncapexp & $\begin{array}{l}0.051^{\star *} \\
(0.026)\end{array}$ & $\begin{array}{c}0.051^{*} \\
(0.027) \\
\end{array}$ & $\begin{array}{l}-0.02 \\
(0.08) \\
\end{array}$ \\
\hline $\operatorname{lnh} c$ & $\begin{array}{c}0.287^{\star * *} \\
(0.056)\end{array}$ & $\begin{array}{c}0.183^{\star * *} \\
(0.064)\end{array}$ & $\begin{array}{c}0.849^{* * *} \\
(0.258)\end{array}$ \\
\hline lngov & $\begin{array}{c}0.037^{\star} \\
(0.021)\end{array}$ & $\begin{array}{l}0.038^{\star} \\
(0.02)\end{array}$ & $\begin{array}{c}0.036^{*} \\
(0.021)\end{array}$ \\
\hline$r d c$ & $\begin{array}{c}0.031 \\
(0.158) \\
\end{array}$ & $\begin{array}{c}-0.812^{\star * *} \\
(0.259)\end{array}$ & $\begin{array}{c}0.245 \\
(0.178) \\
\end{array}$ \\
\hline lc & $\begin{array}{c}-9.766^{\star} \\
(5.005)\end{array}$ & $\begin{array}{l}-2.117 \\
(5.217)\end{array}$ & $\begin{array}{c}-14.057^{\star * \star} \\
(4.66)\end{array}$ \\
\hline profitp & $\begin{array}{c}121.519^{* * *} \\
(26.06)\end{array}$ & $\begin{array}{c}146.043^{* * *} \\
(25.727)\end{array}$ & $\begin{array}{c}120.24^{* * *} \\
(23.226)\end{array}$ \\
\hline lneps & $\begin{array}{c}0.616^{* * *} \\
(0.065)\end{array}$ & $\begin{array}{c}0.534^{* * *} \\
(0.069)\end{array}$ & $\begin{array}{c}0.636^{* * *} \\
(0.063)\end{array}$ \\
\hline lnasset & $\begin{array}{c}0.455^{\star * *} \\
(0.063)\end{array}$ & $\begin{array}{c}0.407^{\star * *} \\
(0.066)\end{array}$ & $\begin{array}{c}0.472^{\star * *} \\
(0.064)\end{array}$ \\
\hline
\end{tabular}


End of Table A4

\begin{tabular}{|c|c|c|c|}
\hline & (14) & (15) & (16) \\
\hline & lnebit & lnebit & lnebit \\
\hline growth & $\begin{array}{l}-1.804 \\
(4.902) \\
\end{array}$ & $\begin{array}{l}-1.904 \\
(4.902)\end{array}$ & $\begin{array}{l}-0.194 \\
(4.357) \\
\end{array}$ \\
\hline lev & $\begin{array}{c}-5.496^{\star * *} \\
(0.661)\end{array}$ & $\begin{array}{c}-6.016^{\star * *} \\
(0.843)\end{array}$ & $\begin{array}{c}-5.659^{* * *} \\
(0.651)\end{array}$ \\
\hline cash & $\begin{array}{c}-0.04 \\
(0.027) \\
\end{array}$ & $\begin{array}{c}-0.02 \\
(0.021) \\
\end{array}$ & $\begin{array}{l}-0.038 \\
(0.028) \\
\end{array}$ \\
\hline turnover & $\begin{array}{l}0.048^{\star *} \\
(0.021)\end{array}$ & $\begin{array}{l}0.035^{\star *} \\
(0.016)\end{array}$ & $\begin{array}{c}0.05^{\star *} \\
(0.022) \\
\end{array}$ \\
\hline concen & $\begin{array}{c}-0.045^{\star *} \\
(0.019)\end{array}$ & $\begin{array}{c}-0.047^{* *} \\
(0.019) \\
\end{array}$ & $\begin{array}{c}-0.049^{* * *} \\
(0.018)\end{array}$ \\
\hline Inmshare & $\begin{array}{c}0.03 \\
(0.018)\end{array}$ & $\begin{array}{c}0.029 \\
(0.018) \\
\end{array}$ & $\begin{array}{c}0.027 \\
(0.018) \\
\end{array}$ \\
\hline $\ln r d^{*} r d c$ & & $\begin{array}{c}1.012^{\star * \star} \\
(0.261)\end{array}$ & \\
\hline $\operatorname{lncapexp}{ }^{*} r d c$ & & $\begin{array}{c}0.154 \\
(0.152) \\
\end{array}$ & \\
\hline $\operatorname{lnh} c^{*} r d c$ & & $\begin{array}{c}-0.536^{\star *} \\
(0.245)\end{array}$ & \\
\hline $\ln r d^{*} l c$ & & & $\begin{array}{c}-14.233 \\
(9.194) \\
\end{array}$ \\
\hline $\operatorname{lncapexp}{ }^{*} l c$ & & & $\begin{array}{c}-11.032^{* * \star} \\
(3.45)\end{array}$ \\
\hline $\operatorname{lnh} c^{*} l c$ & & & $\begin{array}{c}17.23 \\
(10.586) \\
\end{array}$ \\
\hline industry & yes & yes & yes \\
\hline province & yes & yes & yes \\
\hline year & yes & yes & yes \\
\hline Constant & $\begin{array}{c}-1.857^{* * *} \\
(0.345)\end{array}$ & $\begin{array}{c}-2.062^{\star * *} \\
(0.341)\end{array}$ & $\begin{array}{c}-1.899^{* * *} \\
(0.31)\end{array}$ \\
\hline No. of Obs. & 715 & 715 & 715 \\
\hline$R$-squared & 0.804 & 0.819 & 0.811 \\
\hline
\end{tabular}

Notes: Clustered robust standard errors are in parentheses. ${ }^{* *},{ }^{* *}$ and ${ }^{*}$ denote statistical significance at $1 \%, 5 \%$ and $10 \%$ levels, respectively. lnebit, economic performance; lnrd, R\&D input; lncapexp, expansion of production capacity for existing products; $\operatorname{lnh} c$, human resource training; lngov, government subsidies; $r d c$, proportion of $\mathrm{R} \& \mathrm{D}$ operating expenses; $l c$, proportion of human resource training cost; profitp, profitability; lneps, capital profitability; lnasset, size; growth, growth ability; lev, financial risk; cash, short-term solvency; turnover, operating ability; concen, equity concentration; lnmshare, management shareholding. 